\title{
Opportunities and Challenges in Marketing of Agricultural Inputs and Outputs: The Case of Damot Farmers' Cooperative Union, Amhara Region
}

\author{
Yilkal Andualem Demeke
}

\begin{abstract}
Cooperatives, as economic enterprises and as self-help organizations, play a meaningful role in uplifting the socioeconomic conditions of their members and their local communities. MPCSs improve farmers' access to agricultural inputs and market agricultural outputs and increase their bargaining power. This research conducted on opportunities and challenges of marketing of agricultural inputs and outputs in Damot Farmers' cooperative union, Amhara region, Ethiopia. The main objectives were to investigate the opportunities and challenges in marketing agricultural inputs and outputs, in the case of Damot farmers' cooperative union, Amhara Region. To accomplish this study both primary and secondary sources of data were used. Moreover, multi-stage sampling technique was employed at five-stage to select Bure Wereda, 6 MPCSs and 140 sample respondents on basis of systematic random sampling technique. Structured interview schedule used to collect primary data from famer members. And, data analysis carried out using descriptive statistics like frequency, mean, standard deviation, minimum and maximum values employed using SPSS software version 20 to investigate factors that determine the volume of agricultural input and output marketing and possible opportunities and challenges of cooperative societies. The results of performance of MPCSs were also presented organizing into two categories such as functional and financial performances. Volume of agricultural input and output marketing were used as key factors to analyze cooperatives' performance and opportunities and challenges in agricultural input/output marketing in the study area. Improving members awareness, providing training and education for members, hiring professional management, increasing the financial power of cooperatives through sales of shares and running profitable business, developing vertical and horizontal integration of cooperatives and application of experience sharing among cooperatives were some of the intervention areas need to be considered by concerned stakeholders in the study area to improve the agricultural input and output marketing of cooperative societies.
\end{abstract}

Keywords: Agricultural cooperatives, Agricultural inputs and outputs

DOI: $10.7176 / \mathrm{DCS} / 9-3-04$

Publication date:March $31^{\text {st }} 2019$

\section{INTRODUCTION}

\subsection{Background of the Study}

Agricultural Development is in a crisis in Ethiopia. Agriculture is the major source of employment, revenue and export earnings. The challenges facing Ethiopia are daunting: the dynamics of population growth, land degradation, very low productivity, structural bottlenecks, dependence on unreliable rainfall, and being land-locked combine to pose challenges almost unequalled anywhere in the world. Government efforts to accelerate progress as rapidly as possible - including a big push on education, expanding infrastructure, uplifting the economy, building institutions, and devolving (decentralize) administration- are like those of an athlete running uphill: extra-efforts are required just to keep the pace (MoFED, 2006).

Ethiopia's vision in the economic sector is "to build an economy which has a modern and productive agricultural sector with enhanced technology and an industrial sector that plays a leading role in the economy; to sustain economic development and secure social justice; and, increase per capita income of citizens so that it reaches at the level of those in middle-income countries." Since 2003/04, the economy has shifted to a higher growth trajectory and the growth momentum has been sustained during the PASDEP period (2005/06-2009/10). Infrastructure development and social services has expanded. Involvement of private investors and the community in general has reached its encouraging level. Domestic resource mobilization effort has increased the capacity of the country to finance development projects. The process of laying-out foundation for democracy and good governance has been given emphasis through several reform programs. The Growth and Transformation Plan(GTP) is directed towards achieving Ethiopia's long term vision and sustaining the rapid and broad based economic growth anchored on the experiences that has been drawn from implementing development policies and strategies and undertaking policy measures for the challenges that has been surfaced in the course of implementation. The overriding development agenda of GTP is to sustain rapid and broad-based growth path witnessed during the past several years and eventually end poverty (MoFED, 2010) (GTP, 2010).

The concept of human cooperation is not new. It was existed even before the formation of modern cooperative. The Rockdale society of equitable pioneers Ltd 1844 is the first successful consumer cooperative business. A group of 28 traders' in England formed it as consumer (buyers) cooperative. The cooperative was having its own 
business practices (principles) which made the cooperative successful (Zerihun, 1998).

Co-operation as a way of life has been and continues to be a tradition in finding the solution to the socioeconomic problems of the people in Ethiopia. Examples of such cooperation can be found everywhere in the working of mutual aid institutions such as Equb, Eddir, Wonfel or Jigii, senbete, and many others. The traditional cooperation among the rural community was a ground to the flourishing of modern cooperation in early 1960s, realizing that these traditional institutions failed to meet the requirements of credit services and equipment needed for productive purposes in full. In all circumstances the program for cooperative development was, therefore, formulated and had been included in the second Five-year Development plan (1962-67) of the country (Ibid).

The Derg regime established an extensive network of socialist agricultural cooperatives throughout Ethiopia by organizing the peasants. There was virtually no member participation. Instead, party agents and political activists largely ran these cooperative systems. Corruption and mismanagement were so prevalent in the service cooperatives, which handled the purchase of consumer goods for rural communities, which basic goods such as soap, salt, sugar and paraffin oil were generally in desperately short supply in the cooperative shops (Dessalegn, 1994).

The existing government abolished the command economy and introduced economic and political liberalization, including steps to promote the development of democratically governed, market oriented, member owned cooperatives; and professionalism in the management of cooperatives. In addition, the government has placed a high priority on food security and self-sufficiency. Cooperatives are promoted as part of Ethiopian rural and agricultural development strategies, within the national macroeconomic policy framework of agricultural development led industrialization (ADLI) (MoFED, 2006).

Cooperatives: a cooperative is an autonomous association of persons united voluntarily to meet their common economic, social and cultural needs and aspirations through a jointly owned and democratically controlled enterprise. Cooperatives, as economic enterprises and as self-help organizations, play a meaningful role in uplifting the socio-economic conditions of their members and their local communities. The Government of Ethiopia has identified the cooperative form of business organizations as instrumental to socio-economic development and has supported cooperatives for decades to improve agricultural production and productivity. The Federal Cooperative Agency (FCA) recognizes approximately 40,000 cooperatives in Ethiopia, of which about 25\% are agricultural in nature. Of these roughly 10,000 cooperatives, approximately 3,000 focus on a single agricultural commodity or irrigation, while the majority of the remaining 7,000 multipurpose cooperatives concentrate primarily on agriculture. In total, it is estimated that about 7 million Ethiopians are members of cooperatives (ATA, 2014).

Within the above context, cooperative promotion office/bureaus have been established at regional and federal level to launch the extension of on-going cooperative development effort to benefit small scale farmers and to promote the spirit of self-help community organization: as an integral part of farming communities' development. Consequently, several agricultural cooperatives (Primary and Secondary) have been established in many parts of the country, not only to benefit members, but also benefit rural communities.

In line with these realities, the research will attempt to analyse the opportunities and challenges, and role and functions of cooperatives in agricultural inputs and outputs marketing through evaluating their marketing performances, and identifying the Strength and weakness of cooperatives. Besides, based on findings of the research recommendations will be provided to enhance cooperatives' contribution in the economic development of the country via resolving the challenges and empowering opportunities in agricultural inputs and outputs marketing.

\section{BACKGROUND INFORMATION}

Cooperative is a special group of people with mutual interest to solve their individual problems through common efforts and ultimately attaining economic and social empowerment to the group members and the community. The prime objective of cooperatives is to solve problems that individuals failed to address independently. Accordingly, cooperatives are involving in inputs/outputs marketing activities, credit provision and providing other services to the members (Zerihun, 1998).

The weak performance of the agricultural marketing (both inputs and outputs markets) in Ethiopia has been portrayed in various studies as a major impediment to growth in the agricultural sector and the overall economy (Dawit, 2005).

However, there should be clear understanding on the bottlenecks in implementing the agricultural inputs/outputs marketing activities by cooperative societies. With the tremendous growth in size and operations and complexity of agricultural marketing, cooperatives are facing a big challenge from both their members and management, and the competitors. It is found that agricultural cooperatives have had limitations by meeting efficiently the needs of their farmer members (Dawit, 2005). Thus, the major challenge facing the agricultural cooperatives is how to operate and meet the needs of the members efficiently and effectively keeping in mind the basic principles of cooperation.

Another constraint being faced by cooperatives in playing their role is their limitation to keep continues the 
members' patron on their undertakings. The farmer members are expected to be loyal to cooperatives and vice versa. But it is apparently known that if cooperatives fail to meet members' demand or members do not get any definite benefits from the existing cooperatives, they do not keep on their membership or cease to participate in the activities of the cooperatives. This is so because the farmer members' participation on agricultural marketing can only is enhanced based on concrete or tangible benefits. As a result, it is very often complained that participation of members in the cooperatives is very poor (Dawit, 2005). So, the evaluation of performance of Multi-Purpose Cooperative Societies (MPCSs), and identification of problems facing cooperatives are critical areas, which will be studied in order to see whether MPCSs really are playing their role in the study area.

The agricultural markets in Ethiopia are highly influenced by the production system itself. Most of the agricultural production is undertaken by small scale producers scattered all over the country, engaged in different agricultural enterprises without specialization, and with limited marketable surplus. Gebremeskel (2002) estimated that only 28 percent of total farm output in 2001 was marketed. Therefore, the scattered produce in small quantity needs to be collected and assembled, graded, and transported from one market level to another. Thus, the marketing system is characterized with a long chain with many intermediaries. An intervention is required to shorten the marketing channel in order to reduce the marketing costs incurred at each level of marketing channel so that the benefits will go to the farmers.

Although cooperatives are considered as an appropriate tool of rural development they are facing critical problems, which retain them from their positive role. Some of the constraints of cooperatives are: low institutional capacity, inadequate qualified personnel, low entrepreneurship skill, lack of financial resources, lack of market information, poor members' participation in the different activities such as financing the cooperative, patronizing the business activities of the cooperatives, control and supports it. Moreover, the prices of agricultural inputs are increasing from year to year and farmers are complaining on it. These multifaceted problems make very difficult the overall activities of the cooperatives in general and the agricultural inputs and outputs marketing in particular. The aforementioned problems place the farmers as usually price takers due to the fact that they have poor marketing skill and limited bargaining power. There have been attempts made by the government to improve the marketing skill and bargaining power of farmers through establishment of cooperatives and promoting other group action approaches (Dawit, 2005).

To the knowledge of the researcher, there is dearth of studies on the opportunities and challenges of cooperatives in inputs/outputs marketing in the study area. Hence the this study is unique and it makes an attempt to bring forth the opportunities and challenges, marketing performances and sort outing the strength and weakness of cooperatives in agricultural inputs and outputs marketing of Damot Farmers' Cooperative union in Bure Woreda, West Gojjam Zone, Amhara National Regional State.

\section{OBJECTIVES OF THE STUDY}

The general objective of the study is to investigate the opportunities and challenges in marketing agricultural inputs and outputs, in the case of Damot farmers' cooperative union, Amhara Region.

Specific objectives

1. To assess the performance of union in agricultural inputs and outputs marketing

2. To identify the prospects of Cooperatives better future in marketing of agricultural input and output

3. To Assess internal, external and infrastructural challenges of cooperatives in agricultural inputs and outputs marketing

4. To propose the interventions required to solve the problems faced by the cooperatives.

\section{SCOPE OF THE STUDY}

The researcher used descriptive research approach and the data were collected in between January 2014 and May 2014.Due to the purpose of the study, not all the MPCSs involved in agricultural inputs and outputs marketing activity found in the study area. Samples of six multipurpose primary cooperatives were randomly selected from the total MPCSs found in Bure woreda. The study was confined to rural agricultural cooperatives which are engaged in agricultural inputs and outputs marketing which comprised Damot farmers' cooperative Union. The result represents the conditions in West Gojjam Zone of Bure Woreda, Damot Farmer's Cooperative Union, therefore the results cannot be generalized to the whole part of Ethiopia.

\section{MATERIALS AND METHODS}

The types of research employed under this study were descriptive research. This study describes and critically assesses the opportunities and challenges in marketing of agricultural inputs and outputs of Damot Farmers' Cooperative Unionin the study areas. In this study, a combination of qualitative and quantitative approaches of doing research was employed, which has been practiced, as recommended by Creswell (2009:203-216).Many researchers who use both methods gain the best of both quantitative and qualitative research approaches (Kothari, 2004). 
The appropriate Data for the purpose of this study were collected from both primary and secondary sources to answer the research questions and objectives of the study accordingly. Secondary data also were collected from different sources such as baseline information of the schemes, development plans (five-year strategic plans, annual plans), and annual reports of Bure Woreda, Damot Farmers' cooperative Union, West Gojjam Zone cooperative promotion Bureau, and ANRS CPDA, Journals, CSA publications, published and unpublished documents.

In this research various primary data collection techniques were utilized based on their fitness to the study. These are interview schedule; focus group discussions (FGD), key informant (KI) interview as well as personal observations were accordingly used during transect walks in the woreda.

The main participants of the study were multipurpose cooperatives which are legally organized and registered by cooperative promotion office and engaged in the marketing of agricultural input and procurement and merchandising of outputs with the farmer members. Multi stage sampling technique at five levels was employed for the purpose of this study for the selection of the study area, multipurpose cooperatives and sample respondents. In the first stage, Bure woreda was purposely selected for this study. The scenario behind it is Damot Farmers' Cooperative union, which is the target of this study, is found in West Gojjam Zone, Bure Woreda. In the second stage, Considering the total number of 11 primary multipurpose farmers' cooperative comprised under Damot Farmers' Cooperative Union in study area as well as resource, time and the representativeness of the sample, 54.5\% (6 primary multipurpose farmers' cooperatives society) is randomly drawn using lottery method, from different directions of the woreda to ensure adequate representation. In third stage, the number of sample respondents were determined based on Becker's formula, on $4^{\text {th }}$ stage to determine the sample size from each sample MPCSs the probability proportionate technique was followed and on $5^{\text {th }}$ stage systematic random sampling were employed to select the respondents total of 140 cooperative members are selected as a respondent mainly to collect primary data employing systematic random sampling, after taking a list of members from each multipurpose cooperative in the woreda which included under Damot Farmers' Cooperative Union.

Cooperative Promotion agents were recruited from the study area and acquainted with the questions, training on methods of data collection and interviewing techniques. Individual farmers who are members of the cooperatives were interviewed by using a structured questionnaire.

To make the study more effective focus group discussions (FGD) was conducted in every sample multipurpose cooperative villages to gather qualitative information from members as well as cooperative promoters. Hence, six FGDs having each seven members focused on the research issues were carried out among members, non-members, and extension workers so as to avoid specific group's idea dominancy and to get triangulated data.

Secondary data were collected from various sources according to their relevance to the purpose of the study. Documents prepared by the cooperatives like agendas, financial statements, members list were used. From the ANRS CPDA, West Gojjam Zone Cooperative Promotion and Development Bureau, Bure woreda cooperative promotion and development office and Damot farmers' cooperative union office, documents directly related with areas of the research were gathered such as list of cooperative societies, general written information about the cooperatives activities, and others.

For the analysis, after completion of the data collection, entering the raw data in to SPSS version-20 computer aided statistical packages was done for the analysis purpose.

The collected data were analyzed by using different quantitative statistical procedures and qualitative methods that help to address research objectives. Thus, descriptive statistical tools like frequency, percentage, mean and standard deviation were extensively used to explain the demographic, economic, Personal, Income and expenditure, Farming, Institutional characteristics and of respondents, and other issues comprised the research objectives. The qualitative data were partly analyzed on spot during data collection to avoid forgetting and to be able to identify the gaps to be covered through subsequent data collection.

Qualitative data especially related to opportunities and challenges, its performances, the roles of cooperatives provided to the community, and the suggestion of members of each multipurpose cooperative in agricultural marketing were interpreted by using interpretations, categorizations, and narrative explanation of facts to supplement the findings of quantitative data analysis.

\section{RESULTS AND DISCUSSION}

This part of the thesis presents the findings and discussion of the study under different parts. In this study descriptive statistics tools like frequency, percentage, mean and standard deviation were extensively used to explain the demographic and economic characteristics of respondents, and other issues comprised the research objectives by employing statistical software called SPSS Version 20. Qualitative data especially related to opportunities and challenges, its performances of each multipurpose cooperative in agricultural marketing were interpreted by using interpretations, categorizations, and narrative explanation of facts to supplement the findings of quantitative data analysis. 


\section{Demographic situations of Respondents}

Households are important institutional units that for most development process including agricultural input and output marketing. Thus, discussing on the demographic features of respondents had a vital role to see the conditions of performance in relation with household characteristics.

The age distribution of sample farmers range from 24 to 72 minimum and maximum respectively. The average age of sampled members was 41.29 years. This signifies the sample farmers are at an economically productive age. As depicted in Table 4.1, the majority131 (93.6\%) of the sampled respondents lie within age range of 24-60 while the remaining $(6.4 \%)$ are above age of 60 . This implies that most of $(93.6 \%)$ members of the multipurpose cooperatives at the study area are found to be economically productive (15-64) compared to the more aged ones. This may create favorable opportunities for bringing changes within Cooperatives.

Table 4.1: Socio-demographic characteristics of respondents

\begin{tabular}{|c|c|c|}
\hline List & Number of respondents & Percent (\%) \\
\hline \multicolumn{3}{|l|}{ Sex } \\
\hline Female & 35 & 25.0 \\
\hline Male & 105 & 75.0 \\
\hline \multicolumn{3}{|l|}{ Educational Status } \\
\hline Illiterate & 41 & 29.3 \\
\hline Read and write & 25 & 17.9 \\
\hline Primary School & 63 & 45.0 \\
\hline High School & 8 & 5.7 \\
\hline$>$ High School & 3 & 2.1 \\
\hline \multicolumn{3}{|l|}{ Age distribution } \\
\hline $24-60$ & 131 & 93.6 \\
\hline$>60$ & 9 & 6.4 \\
\hline Minimum & $(24)$ & \\
\hline Maximum & $(72)$ & \\
\hline Mean & $(41.29)$ & \\
\hline Std.dev. & $(11.03)$ & \\
\hline
\end{tabular}

Source: Survey of April, 2014.

Better educational background of farmer members is believed to have positive impact on their readiness and ability to accept new ideas innovation, and technology than uneducated ones. Jemal (2008) discussed on his paper the role of education to motivate and let members participate on cooperative affairs because of members who are literate have an opportunity to be acquainted with the right and obligation they have in the cooperative society. As shown in the (table 4.1)above $25(17.9 \%$ ) of members of sample respondents have read and write $63(45 \%$ have attended primary education, $8(5.7 \%)$ and $3(2.1 \%)$ were attended High school and above high school respectively while $41(29.3 \%)$ were illiterate. This implies most of the members in the study area were attend primary school and above. This is a good opportunity for the cooperatives to inculcate and train the members to produce better leaders for betterment of its marketing role in the area. These can further strengthen the cooperatives involvement in business activities, marketing of outputs effectively and satisfy members on maximum possible services rendered. The study result is consistent with the study result of kisi, (2013), that the literacy rate of cooperative members is high, it is promising for further strengthening the cooperative society.

Females are the half of our countries population though their participation in cooperatives has a great problem in proportion with passive involvement in cooperative society's affairs. From the total sample farmer members studied in the research area, $25 \%$ and $75 \%$ were female and male headed house hold respectively. 80 percent of female respondents are not actively participating in agricultural output marketing of cooperatives. The study result is consistent with the study result of Jemal, 2008, that female representation in cooperatives is lower though the trend is promising.

\section{Income and Expenditure Characteristics}

Agricultural income of Households is determined by household's agricultural production activities and changes in factors influencing these agricultural production activities. The agricultural household income was estimated based on the sales of crops produced, livestock and off-farm income the farmer or any of the household members earned in the year.

\section{On-Farm Income of sample Cooperative members}

Annual On-farm income of sample Cooperative member respondents was 4,601,400.00 birr. The average on farm income of cooperative members is $32,867.14$ birr/year with standard deviation of 27,711.24 and it shows the great difference of income among the sample respondents. The minimum annual on-farm income of the sample respondents were 2,000.00 and the maximum annual on farm income of the cooperative sample members were $150,000.00$ birr/annum. 
Table 4.2:Sources and Annual on-farm Income of Sample respondents

\begin{tabular}{|l|c|l|l|}
\hline N.o & On-Farm Activities & Number of Respondents & Percent \\
\hline 1 & Cereal and Pulses & 37 & 30.7 \\
\hline 2 & Livestock & 4 & 2.2 \\
\hline 3 & Horticulture & 2 & 1.4 \\
\hline 4 & All agricultural activities & 87 & 69.8 \\
\hline \multicolumn{2}{|c|}{140} & 100 \\
\hline
\end{tabular}

Source- Survey of April, 2014.

The major sources of cash income were from the sale of Cereals and Pulses, Live stocks and Horticulture. Besides, all livestock, cereals, pulses and vegetables on average contribute 92.86 per cent of the total annual income per household of the sampled farmers.

Table 4.3: Distribution of Annual Income, on-farm and non-farm income, and Annual expenditure of sample cooperative members.

\begin{tabular}{|l|l|l|l|l|}
\hline \multirow{2}{*}{ Statistics } & \multicolumn{4}{|l|}{ Types of Income of sample respondents } \\
\cline { 2 - 5 } & On-farm & Non-farm & Total Annual Income & Expenditure \\
\hline Minimum & $2,000.00$ & 0 & $2,000.00$ & 500.00 \\
\hline Maximum & $150,000.00$ & $20,000.00$ & $150,000.00$ & $126,000.00$ \\
\hline Mean & $32,867.14$ & $2,525.00$ & $35,392.14$ & $21,135.36$ \\
\hline St. deviation & $27,711.24$ & $3,501.88$ & $29,057.56$ & $20,360.23$ \\
\hline
\end{tabular}

Source: Survey of April, 2014.

There was significant difference in the mean annual income from on-farm activity. Sales of crops and livestock are the major cash income sources for the households in the study area. About 30.7 per cent of the total sample respondents earned cash income from sales of cereals and pulses whereas about 69.3 per cent of the sample respondents earned cash income from sales of cereals, pulses, vegetable and livestock and /or livestock by-products (Table 4.2).

\section{Non- Farm Income}

The income earned from the members economic activity of non-farm income were made through daily labor, Petty trade, Handy-craft, Fuel wood selling, and Homemade drinks. The average non-farm income of the sample respondents were 2,525.00 Birr/annual participating members with minimum of birr 0 and maximum of 20,000.00 birr/annum. 7.14 percent of the total income earned is from non-farm activities of the respondents. (Table 4.4) shows the distribution of households by non-farm income. There was significant difference in the mean annual income from farm and non-farm activity of sample respondents.

Table 4.4: The Non-Farm Annual income of Sample Members in percentage

\begin{tabular}{|l|l|l|l|}
\hline N.o & Non-farm Activities & Respondents & \% \\
\hline 1 & Daily Labor & 22 & 15.7 \\
\hline 2 & Petty Trade & 31 & 22.1 \\
\hline 3 & Handicraft & 10 & 7.1 \\
\hline 4 & Fuel Wood Selling & 9 & 6.4 \\
\hline 5 & Home Made drink & 11 & 7.9 \\
\hline 6 & None & 57 & 40.7 \\
\hline & Total & 140 & 100 \\
\hline
\end{tabular}

Source: Survey of April, 2014.

Annual income of respondents

Annual income is an income that is secured in given production year. The annual income of the households in study area is a summation of crop production, rearing of livestock, horticultural productions and earning on nonfarm activities. The average household income of the sample respondents was found to be Br.35, 392.14. The mean difference between two groups was Birr 856.27 which is highly substantial. As the study reveals that there is significant difference in total annual income of household between members who are participating in the cooperatives input and output marketing.

\section{Expenditure of member respondents}

The amount of expenditure is an important variable that influences the amount of inputs the members purchase from their cooperatives and the amount of agricultural outputs that member's supplied for cooperative societies. The annual expenditure of respondents in the study area shows a great disparity between the high and low income groups. Table 4.3 shows distribution of sample households by total annual expenditure per household. Sampled farmers on average spent Br. 21,135.36 per household with standard deviation of 20,360.23. As the study reveals that the mean difference between members in relation to expenditure per household was very high and had influence on marketing of agricultural inputs and outputs with cooperative societies. 


\section{Personal Characteristics of Respondents}

\section{Participation of respondents in cooperative affairs}

Participation of members is the core function that the cooperatives required for strengthening their financial, organizational and functional performances. The study examines the participation of all the respondents in cooperatives by using the components of participation that were identified based on literature reviews. For this study purpose 8 participation indicators were used and measured the degree of participation: in attending meeting, approving by-law, electing management committee and board of directors, approving annual plan and budget, approving audit report, financing the cooperative society, evaluating the management committee and sharing responsibility.

The result of the study shows that 20 per cent of the total sample respondent ( 28 respondents) found to have relatively high level of participation, 54.3 percent of the respondents ( 76 respondents) were participate sometimes while 25.7 per cent of the respondents (36 respondents) had low participation in attending meetings(Table 4.5).

Table 4.5: Participation of Sample Respondents in Cooperative affairs

\begin{tabular}{|l|l|l|l|l|l|l|}
\hline \multirow{2}{*}{ Participation indicators } & \multicolumn{2}{l|}{ Not at all (0) } & \multicolumn{2}{l|}{ Sometimes (1) } & \multicolumn{2}{l|}{ Always (2) } \\
\cline { 2 - 7 } & Cut & $\mathbf{( \% )}$ & Cut & $\mathbf{( \% )}$ & Cut & $(\%)$ \\
\hline Attending meeting & 36 & 25.7 & 76 & 54.3 & 28 & 20 \\
\hline Approving by-law & 38 & 27.1 & 67 & 47.9 & 35 & 25 \\
\hline Electing management committee \& Board of directors & 86 & 61.4 & 24 & 17.1 & 30 & 21.3 \\
\hline Approving Annual Plan and budget & 38 & 27.1 & 63 & 45 & 39 & 27.9 \\
\hline Approving Audit Report & 59 & 42.1 & 55 & 39.3 & 26 & 18.6 \\
\hline Financing the cooperative society & 95 & 67.9 & 34 & 24.3 & 11 & 7.9 \\
\hline Evaluating the management committee & 51 & 36.4 & 61 & 43.6 & 28 & 20 \\
\hline Sharing responsibility & 59 & 42.1 & 63 & 45 & 18 & 12.9 \\
\hline Total & 462 & 41.2 & 443 & 39.6 & 215 & 19.2 \\
\hline
\end{tabular}

Source: Survey of April, 2014

The study also 'revealed that 25 per cent of the total sample respondent ( 35 respondents) found to have relatively high level of participation, 47.9 percent of the respondents (67 respondents) were participate sometimes while 27.1 per cent of the respondents (38 respondents) had low participation in Approving cooperative societies by-laws. 21.3 per cent of the total sample respondent (30 respondents) found to have relatively high level of participation, 17.1 percent of the respondents ( 24 respondents) were participate sometimes while 61.4 per cent of the respondents ( 86 respondents) had low participation in electing management committee and board of directors. 27.9 per cent of the total sample respondent (39 respondents) found to have relatively high level of participation, 45 percent of the respondents (63 respondents) were participate sometimes while 27.1 per cent of the respondents (38 respondents) had low participation in approving annual plan and budget of the cooperative society. 18.6 per cent of the total sample respondent (26 respondents) found to have relatively high level of participation, 39.3 percent of the respondents (55 respondents) were participate sometimes while 42.1 per cent of the respondents (59 respondents) had low participation in approving audit report. 7.9 per cent of the total sample respondent (11 respondents) found to have relatively high level of participation, 24.3 percent of the respondents (34 respondents) were participate sometimes while 67.9 per cent of the respondents (95 respondents) had low participation in financing the cooperative society through buying additional shares. 20 per cent of the total sample respondent (28 respondents) found to have relatively high level of participation, 43.6 percent of the respondents (61 respondents) were participate sometimes while 36.4 per cent of the respondents (51 respondents) had low participation in evaluating the management committee. 12.9 per cent of the total sample respondent (18 respondents) found to have relatively high level of participation, 45 percent of the respondents (63 respondents) were participate sometimes while 42.1 per cent of the respondents (59 respondents) had low participation in sharing different responsibilities in cooperative societies.

To conclude the result of the study based on the indicators explained 19.2 percent of total participants were actively participate in all cooperative affairs, 39.6 percent of total participants were participating on cooperative affairs sometimes while the rest 41.2 the higher proportion of the respondents were not actively participate on cooperative affairs and this is the bad news for cooperatives better future and growth.

\section{Share Contribution of the Members}

Cooperative societies are organized through sharing of ideas, labor and money by poor peoples who are unable to fulfill their unlimited needs. Sample Cooperative members share contribution result reveals that 10 per cent of sample cooperative members of the total respondents have less than 5 paid-up share capitals in their respective cooperative society. 
Figure 4.1: Distribution of shares owned by Cooperative societies sample respondents

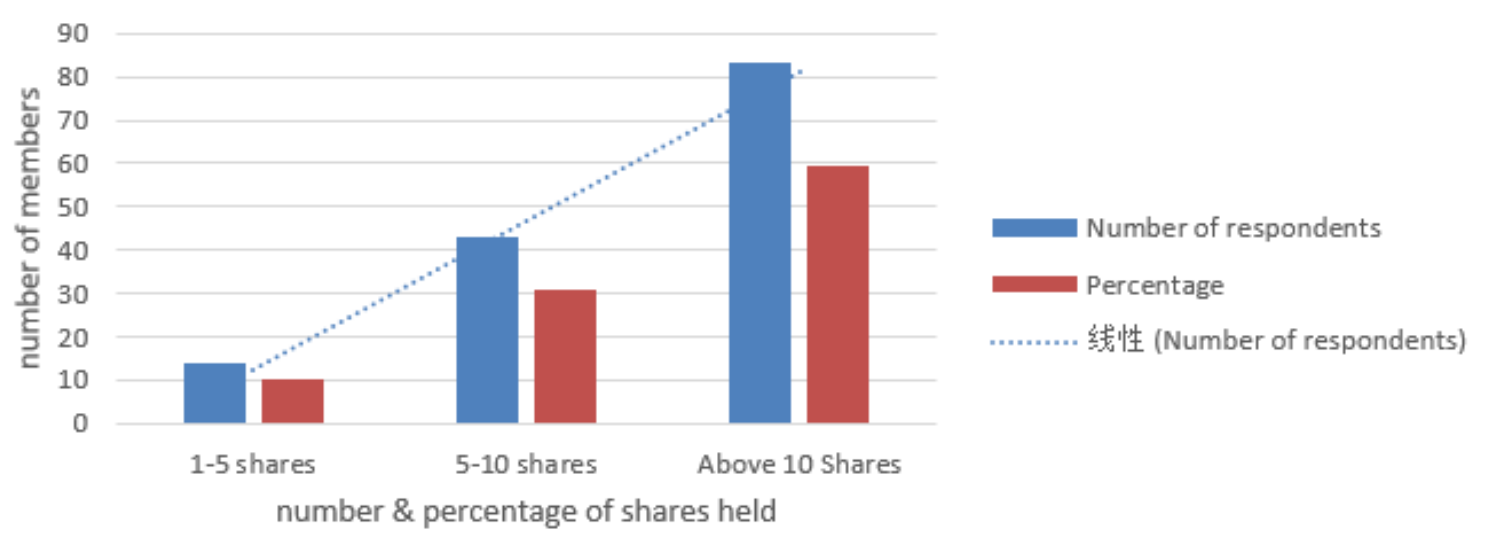

Source: Survey of April, 2014.

As one can show from (Fig. 4.1) 30.7 per cent of the respondents have afford above 5 and less than 10 paidup shares while the rest 59.3 percent of the respondents have greater than 10 paid-up shares within their cooperative societies however it is not enough to strengthen the financial as well as the functional performance of cooperative societies. Additional number of paid up share capital is essential to build up the sense of ownership among members of cooperatives. The study result shows that members who have secured more than 10 Paid-up shares have active participation and have better sense of ownership in the activities of Cooperatives.

\section{Membership Duration and Status}

Membership duration in cooperatives is vital for concluding that the cooperative societies are significant for their members' economical welfare. Otherwise one cannot understand the importance of cooperatives as well as their weaknesses and strengths in serving their members as expected. As the seven great principles of Cooperatives one of it is "voluntary and Open membership", the members of Cooperatives have to be members on their free will and those cooperative societies have to be open whenever everybody who are fulfilled the criterions become a member. However the study reveals that difficulties are encountered when the principle of the "voluntary and open membership", is violated. Co-operatives organized and tightly controlled by government, as instruments of state economic policy are rarely conducive to the development of democratically controlled, member-owned cooperatives (Coward, 2004 as cited by Jemal, 2008). Maximum numbers of members of cooperatives in the study area are becoming members to get credits, fertilizer and improved seeds.

\section{Figure 4.2: Distribution of member's duration in cooperatives}

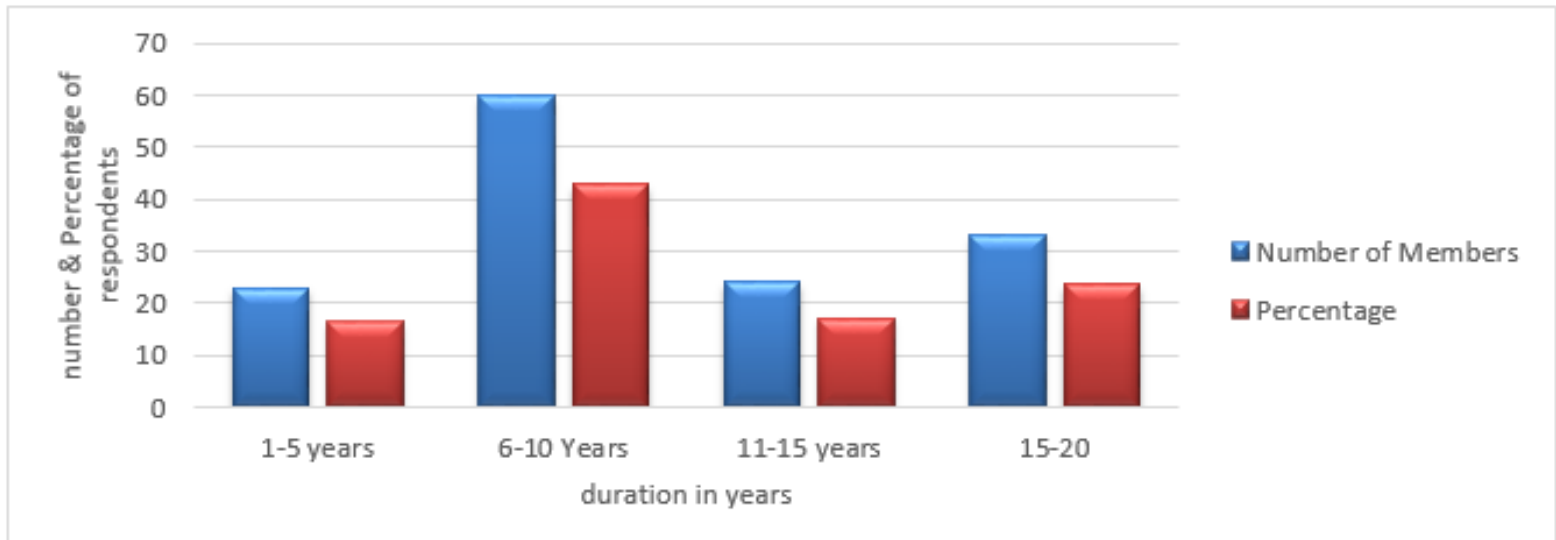

Source: Survey of May, 2014

As we can see from (Fig. 4.2) the members of cooperatives in the study area were becoming members in different periods of time; however there was some form of persuading the farmers at the beginning of organizing cooperatives in the new government. The study result revealed that 23.6 per cent of the total respondents became members for more than 15 years, 17.14 per cent of the total respondents became members in between 11-15 years, 42.9 per cent of the total respondents became members in between 6-10 years starting from 2003 to 2008 there was a great change in increment of membership in the study area, while 16.42 per cent of the respondents became members in between 1-5 years before. As the members get more experience in cooperatives they know more about cooperatives and aware of the utilization of agricultural inputs and increase trust on their cooperatives and it leads 
to bring more agricultural output to their cooperative societies.

\section{Members' awareness about Cooperatives}

As the focus group discussion and key informants interview shows members' awareness about Cooperatives is the core knowledge that is result in success of the cooperative movement. Majority of the sample respondents were have known about cooperatives. From the total sample respondents $122(87.1 \%)$ were respond to they have awareness about Cooperatives while 22(12.9\%) of sample respondents were answered they have not any awareness about Cooperatives they have engaged functions and its merits and demerits for its members.

As we can see from the (table 4.6) below 116(82.9\%) of respondents were well aware about the objective of cooperatives while the rest $24(17.1 \%)$ of the respondents were have not any awareness about their cooperative objectives, $119(85 \%)$ of the respondents were aware of their rights and responsibilities in their cooperatives institution while $21(15 \%)$ of the respondents were lack of awareness about their rights and responsibilities and were not exercise their sides of responsibilities and exploiting their rights for the cooperatives and the wellbeing of themselves, $110(78.6 \%)$ of the sample respondents were aware of the rights and responsibilities as well as the division of power and duration/span of exercising the power of their management committee members while $30(21.4 \%)$ of respondents were not aware of their management committees in general, 129(92.1\%) of sample cooperative members were aware of the services provided by cooperatives while 11(7.9\%) of respondents were not aware of services provided by cooperatives, and $82(58.6 \%)$ of respondents were well aware of the amount of their cooperatives capital but 58(41.4\%) of respondents haven't any know how about the capital of Cooperatives. Table 4.6: Members' awareness about Cooperatives

\begin{tabular}{|l|l|l|l|l|}
\hline No. & Area of Awareness & Response & Number of respondents & Percent \\
\hline 1 & Objective of cooperatives & Yes & 116 & 82.9 \\
\cline { 3 - 5 } & & No & 24 & 17.1 \\
\hline 2 & Rights and responsibilities & Yes & 119 & $(85$ \\
\cline { 3 - 5 } & & No & 21 & 15 \\
\hline \multirow{2}{*}{ Awareness about the management committee } & Yes & 110 & 78.6 \\
\cline { 3 - 5 } & & No & 30 & 21.4 \\
\hline 4 & Services provided by cooperatives & Yes & 129 & 92.1 \\
\cline { 3 - 5 } & & No & 11 & 7.9 \\
\hline 5 & Capital of Cooperatives & Yes & 82 & 58.6 \\
\cline { 3 - 5 } & & No & 58 & 41.4 \\
\hline 6 & General Knowhow about Cooperatives & Yes & 122 & 87.1 \\
\cline { 3 - 5 } & & No & 22 & 12.9 \\
\hline
\end{tabular}

Source: Survey of April, 2014.

Therefore, the study shows that the responsible bodies have to create awareness about cooperative to the members for the healthy movement of the institutions and well-being of members as well. Moreover, there must be a periodic program for announcing the capital and activities of cooperatives to members. This study result is similar to (Jemal, 2008) that cooperatives lack a system that makes them competent in providing services to attract members' comprehensive participation in all activities. The fact is that members' commitment to use cooperatives as marketing outlet or agent depends only as long as they are capable to offer attractive prices or quality services.

\section{Members Satisfaction}

The main objective of cooperatives is to satisfy its members unsatisfied economic and social needs as they are member owned, member controlled, equitable economic participation and voluntary membership are the criterions of the organization. Their members are usually poor, often subsistence, and farmers. Therefore, members' may expect price differences from other alternative market, fair price of output, proximity to the village, good credit provision, stable market condition, good profit dividend and less cost and high quality of services. However, mostly, it could be beyond their capacities to meet all the criteria. 
Table 4.7: Distribution of Perception of Members' Satisfaction on the services rendered through cooperatives

\begin{tabular}{|l|l|l|l|l|l|l|}
\hline \multirow{2}{*}{$\begin{array}{l}\text { Level of } \\
\text { satisfaction }\end{array}$} & \multicolumn{9}{|c|}{\begin{tabular}{l} 
Dimensions of Satisfaction \\
\cline { 2 - 7 }
\end{tabular}} & $\begin{array}{l}\text { Fair price of } \\
\text { input } \\
\text { Output }\end{array}$ & $\begin{array}{l}\text { proximity to } \\
\text { the village }\end{array}$ & $\begin{array}{l}\text { good credit } \\
\text { provision }\end{array}$ & $\begin{array}{l}\text { stable } \\
\text { market } \\
\text { condition }\end{array}$ & $\begin{array}{l}\text { good profit } \\
\text { dividend }\end{array}$ & $\begin{array}{l}\text { less cost \& } \\
\text { high quality } \\
\text { of services }\end{array}$ \\
\hline Not satisfied & $47(33.5 \%) 7$ & $47(33.5 \%) 7$ & $47(33.5 \%) 7$ & $47(33.5 \%) 7$ & $47(33.5 \%) 7$ & $47(33.5 \%)$ \\
\hline Medium & $92(65.2 \%)$ & $92(65.2 \%)$ & $92(65.2 \%)$ & $92(65.2 \%)$ & $92(65.2 \%)$ & $92(65.2 \%)$ \\
\hline Satisfied & $1(0.7 \%)$ & $1(0.7 \%)$ & $1(0.7 \%)$ & $1(0.7 \%)$ & $1(0.7 \%)$ & $1(0.7 \%)$ \\
\hline Mean & 0.6763 & & & \\
\hline St.dev. & $0.48478)$ &
\end{tabular}

Source: Survey of April, 2014.

Accordingly, the study result 33.5 percent of respondents were not fully satisfied in services rendered by cooperatives, like Fair price of input \& Output, proximity to the village, good credit provision, stable market condition, good profit dividend and less cost \& high quality of services. 65.2 percent of respondents were satisfied fairly on the services rendered by cooperatives while 0.7 percent of the respondents were fully satisfied with services rendered by cooperatives in the study area. We can conclude that however more than half of respondents were satisfied with the services rendered by cooperatives, there have to be an improvement on the services for satisfying the whole members who are involved in the cooperatives.

\section{Farming Characteristics of Respondents}

Land is one of the crucial resources in the production process. Land in the rural areas a means of securing wealth and livelihood as farmers major activity is on rearing livestock and ploughing the land for their food consumption as well as marketing a portion of it. Moreover, it is the only means of securing food for a Country not only for farmers but also peoples who are residing in urban areas that are engaging in other activities.

Table 4.8: Distribution of Land use system of sample respondents

\begin{tabular}{|l|l|l|l|}
\hline No. & Land Size & No. of Respondents & Percent \\
\hline 1 & 0 ha & 8 & 0.057 \\
\hline 2 & $0.5-2$ ha & 65 & 46.43 \\
\hline 3 & $2-4$ ha & 60 & 42.86 \\
\hline 4 & $5-8$ ha & 9 & 0.06 \\
\hline & Total & 140 & 100 \\
\hline & Mean & 1.89 & \\
\hline & St. deviation & 1.524 & \\
\hline & Minimum & 0 & \\
\hline & Maximum & 8 & \\
\hline
\end{tabular}

Source: Survey of April, 2014.

Farmers are increasing their production and productivity by using extension services and new technologies on their land. According to the Bure woreda Land Administration office, for the fair distribution of land in the study area in 1997 there was land redistribution program and farmers and youths those without land holding were obtained land based on the family size and the capacity of the Kebele's size of land.

As the information gained from focus groups discussion and the sample respondents at the time of information gathering they use their land for rearing livestock and producing different crops (Wheat, Maize, Teff, Pepper) and Horticultures by using the rainfall season(summer Seasons) and small scale irrigation at minimum level.

The average total farm land size holding was 1.89 ha for sample participants. There are no fallowing practices for participant members due to the farmers have shortage of land in the study area. The maximum and minimum farmland holding is 8.0 ha and 0 hectare of the respondent members respectively. Landless farmers are 8 of the sample participating members. Land holding size and quantity of agricultural input and output were positively related, as the hectare of land increases the members' participation on input and output marketing increases.

Livestock rearing is one of the major activities performed as predominantly an agrarian society in the study area. Livestock provide milk, meat, traction power, income and transport. Moreover, farmers send livestock to market as one of coping mechanisms during food shortage (Jemal, 2008). Livestock owned by the sample households include cattle, sheep and goat, equine and poultry. The total livestock population owned by the sample respondents was 389.31 TLU but 16.4 per cent of the respondents were without livestock. The minimum and maximum number of TLU was 0 and 9.2 for actively participating members. The average holding was 2.78 TLU for both active and passive members respectively. So the survey result demonstrated that the higher the livestock holdings leads to the maximum usage of agricultural inputs (Fig. 4.3). 


\section{Figure 4.3: Livestock Ownership status of Participants}

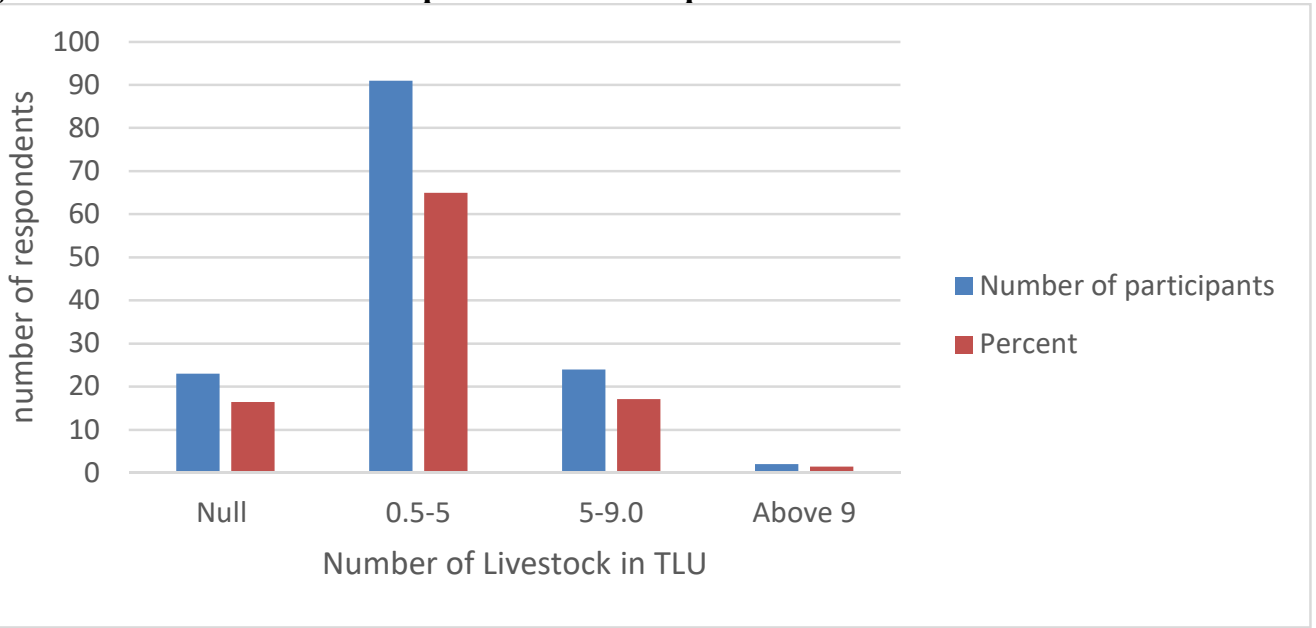

Source: Survey of May, 2014.

\section{Crop production}

Crop production is the major activity that farmers engaged in the study area. The main objective of crop production are producing for consumption purpose and making an income through marketing the agricultural produces. The major crops grown in the study area are barley, wheat, 'Teff', maize, and pepper. Cereals crops are the major agricultural products produced in the study area with the percentage of 97.9 and horticulture crops are produced in minimum percent compared with cereal crops in 2.14 percent annual production.

Table 4.9: Types of Crops produced in the year 2013/2014

\begin{tabular}{|l|l|l|l|}
\hline No. & Types of Crops & Participants & Percent \\
\hline 1 & Cereals & 137 & 97.9 \\
\hline 2 & Horticulture & 3 & 2.14 \\
\hline & Total & 140 & 100 \\
\hline
\end{tabular}

Source: survey result (April, 2014)

\section{Institutional Factor}

\section{Credit Provision}

Damot Farmers' Cooperative Union has Provided Credit provision to member Multi-purpose Cooperative Societies starting from the year of 2001 up to now. Members' credit provision depends on capability of loan repayment history. The respondents were get credit from cooperative societies as well as other financial institutions.

Table 4.10: Respondents' distribution in access to credit

\begin{tabular}{|l|l|c|l|}
\hline Type of service & Response & Number of respondents & Percent \\
\hline \multirow{2}{*}{ Credit access } & Yes & 133 & 95 \\
\cline { 2 - 4 } & No & 7 & 5 \\
\hline Mean & \multicolumn{3}{|c|}{0.95} \\
\hline Std. deviation & \multicolumn{3}{|c|}{0.218} \\
\hline \multirow{2}{*}{$\begin{array}{l}\text { Did get enough amount } \\
\text { of credit }\end{array}$} & Yes & 1 & 0.71 \\
\cline { 2 - 4 } & No & 132 \\
\hline Mean & \multicolumn{3}{|c}{} \\
\hline Std. deviation & \multicolumn{3}{|c|}{0.60} \\
\hline
\end{tabular}

Source: Survey of April, 2014.

The survey result indicates that 95 percent of respondents were obtaining credit from the cooperative societies and other alternative finance institutions while 5 percent of respondents were unable to get credit from any type of saving and credit institutions in the study area. Only 0.7 percent of members were found the required amount of credit while 99.3 percent of members were can not get enough amount of credit for purchasing agricultural inputs, household consumption, and purchase of oxen. The result shows that there are problems in satisfying the members credit needs in the area; moreover farmers can apply the new technologies when they can get enough amount of credit, therefore shortage of credit in the study area created a great influence in achieving great amount of agricultural output growth. 
Table 4.11:Distribution of members and the Purpose of credit and the main sources

\begin{tabular}{|l|c|c|}
\hline Purpose of Credit & Number of respondents & Percent \\
\hline Purchase of Improved seeds & 17 & 12.78 \\
\hline Purchase of Fertilizer & 102 & 76.69 \\
\hline Purchase of Agro-Chemicals' & 2 & 1.5 \\
\hline Purchase of Oxen & 7 & 5.26 \\
\hline Purchase of Household Consumption & 5 & 3.76 \\
\hline Mean & 1.81 & \\
\hline Std. deviation & 0.68 & 1.5 \\
\hline Source of Credit & 2 & 17.29 \\
\hline Neighbor & 23 & 71.43 \\
\hline Money lenders & 95 & 9.7 \\
\hline Cooperative society & 13 & 100 \\
\hline Amhara Credit \& Saving Institution & 133 & \\
\hline Total & & \\
\hline
\end{tabular}

Source: Survey of May, 2014.

As we have seen from (table 4.11) above, the main purpose of credit provision in the study area is for purchase of fertilizer and it accounts 76.69 percent from the total respondents followed by purchase of improved seeds 12.78 percent who are involving in credit services provided through cooperatives. Purchase of agro-chemicals and purchase of household consumption are the least targets covered by credit which accounts 1.5 and 3.76 percent respectively.

The credit provision covered by cooperatives was 71.43 percent the rest respondents were not get credit from cooperative societies and this lead members to search for other institutions for obtaining credit. In addition to its low coverage the loan obtained from cooperatives were not covered the agricultural activities required inputs.

Table 4.12: The Perceived interest rate of credit Sources

\begin{tabular}{|l|c|c|}
\hline Level of interest & Respondents & Percent \\
\hline Low & 16 & 12.0 \\
\hline Medium & 60 & 45.1 \\
\hline High & 43 & 32.3 \\
\hline Very high & 14 & 10.5 \\
\hline Mean & \multicolumn{2}{|c|}{2.41} \\
\hline Std. deviation & \multicolumn{2}{|c|}{0.84} \\
\hline
\end{tabular}

Source: Survey of 2014.

As the study reveals that the perceived interest rate of credit provisions in the study area was 12 percent low, 45.1 percent medium, 32.3 percent high and 10.5 percent very high. From this study we can conclude that however the amount of credit was not enough to cover the required activities its perceived interest rate was fair as 45.1 percent of respondents were answered medium. Loan beneficiaries propose and approve through collaboration of cooperative societies with district level agricultural and rural development and Kebele administrations.

Jemal (2008) according to the by-law of cooperatives, regardless of its source, members must be the only users of available loan. However, considering challenges of farmers to credit access, cooperatives took the responsibility of disbursing loan for the household package to include non-members of their vicinity. The same practice was performed in the study area, all members and non-member farmers were participated in the credit provision especially in agricultural input credit distribution.

\section{Proximity to Market Place}

The use of agricultural input and placing agricultural output to the market were influenced by the farmer's proximity to market. As Key informants interview and respondents in the study area reported that they sold some of their agricultural products right after harvest to cover costs of farm inputs and other expenses by taking to the immediate nearby local market. The survey result indicated that the average distance of respondents' home from the nearest market place was $4.52 \mathrm{~km}$ from among the total respondents, 17.14 per cent lived at a distance above $9 \mathrm{~km}, 55$ per cent of the respondent lived at a distance of $4 \mathrm{~km}$ or below away from the local market and from among them 27.86 percent of the respondent located in a distance between 4-9 km (Table 4.13). The minimum distance was $0.2 \mathrm{Km}$ and the maximum distance was $14 \mathrm{Km}$. The longer distance implies that people less often go to market and more time was required to get to market. 
Table 4.13:Distribution of proximity of market to respondents

\begin{tabular}{|l|l|l|}
\hline Distance (Km) & Number of participants & Percent \\
\hline $0.2-4$ & 77 & 55 \\
\hline $4-9$ & 39 & 27.86 \\
\hline $9-14$ & 24 & 17.14 \\
\hline Total & 140 & 100 \\
\hline Mean & 4.52 & \\
\hline Minimum & 0.2 & \\
\hline Maximum & 14 & \\
\hline
\end{tabular}

Source: Survey result of May, 2014.

\section{Regularity of Market Service}

Regularity of market service is the necessary function that has to be practiced throughout the cooperative societies to handle its members in input and output marketing. As the respondents report that whenever the marketing activities distorted the members are obliged to search for alternative market places to sell their agricultural outputs and procuring products that have not in their home or produced in other places.

Table 4.14: The regularity of market activity of sample cooperative societies

\begin{tabular}{|l|l|l|l|}
\hline Type of service & Response & Number of respondents & percent \\
\hline Continuous marketing activity & yes & 121 & 86.4 \\
\cline { 2 - 4 } & No & 19 & 13.6 \\
\hline Mean & \multicolumn{3}{|l|}{0.86} \\
\hline Std. deviation & \multicolumn{3}{|l|}{0.34} \\
\hline
\end{tabular}

Source: Survey result of May, 2014.

As the study revealed that 86.4 percent of respondents were reported their cooperative societies were engaged in the marketing activity throughout the year without any distortion while 13.6 percent of the respondents were report that their cooperative society were not providing continuous marketing activity because of different internal and external problems.

Table 4.15: The distribution of problems in regular marketing activity

\begin{tabular}{|l|c|c|}
\hline Problems & Number of respondents & Percent \\
\hline Transportation Problem & 2 & 10.5 \\
\hline Shortage of Working Capital & 7 & 36.8 \\
\hline Low Supply of Agricultural Outputs & 3 & 15.8 \\
\hline Stiff Competition in the Market & 4 & 21.1 \\
\hline Others & 3 & 15.8 \\
\hline Mean & \multicolumn{1}{|c|}{1.59} \\
\hline Std. deviation & \multicolumn{2}{|c|}{1.59} \\
\hline
\end{tabular}

Source: survey result of May, 2014.

Those problems were; Shortage of working capital (36.8), low supply of agricultural outputs (15.8), stiff competition in the market (21.1) are the most important problems that contribute for irregular marketing activity in the study area. Transportation problems- however there is a transport service in all sample cooperative societies 3 of 6 cooperatives the transportation service were functional at the winter season only, shortage of working capital is the other important problem which hinder the healthy marketing function of cooperatives throughout the year, low supply of agricultural output were also has its own influence on the regular functioning and stiff competition from the market were important reasons for malfunctioning and distortion of regular marketing activity within cooperatives.

\section{Perceived Agricultural Input and Output Price Disparity}

As information obtained from focus group discussion and key informants interview, cooperatives are organized and operated by members who are economically and socially expected to be benefited from those organizations. Therefore, cooperatives basically stand for safeguarding its members from meddle men exploitation who are involving the market chain, by improving their market access and enhance members negotiation power of agricultural input supply and output marketing in a competitive price. The willingness of farmers to purchase agricultural input and selling outputs are influenced by the expected agricultural input and products prices. As the study revealed that 80.6 percent of respondents were argue that the price of input set by cooperatives was high, 3.6 percent only reported as the price were medium/fair while the minimum number 15.8 percent of respondents were argue as the price of input were low.38.1 percent of respondents were reported they are obtained fair price for their agricultural products while the highest number of respondents 61.9 percent argue they are not obtaining the fair price for their agricultural products from the cooperative societies.

This unfair price setting becomes a great problem for respondents with the problems like; on average all 
purchasers in addition to cooperatives were run for maximum profit, farness from market places, shortage of storage for agricultural produces and inappropriate time for tax and credit.

Table 4.16: Distribution of perceived price of input and output

\begin{tabular}{|l|l|l|l|}
\hline Price of input\& output & Response & Respondent & Percent \\
\hline \multirow{4}{*}{ Inputs } & Low & 22 & 15.8 \\
\cline { 2 - 4 } & Medium & 5 & 3.6 \\
\cline { 2 - 4 } & High & 112 & 80.6 \\
\hline Mean & 2.64 & & \\
\hline Std. deviation & 0.74 & & 38.1 \\
\hline Outputs & Yes & 54 & 61.9 \\
\cline { 2 - 4 } & No & 86 & \\
\hline
\end{tabular}

Source: Survey result April, 2014.

Therefore, when members observed and perceived that the pricing policy of cooperatives is unfair; they refrain to use improved agricultural inputs based on recommended rate and selling their produce to the cooperatives. This will have its own negative consequence in letting them not fully involving in the affairs of cooperatives. The result is in opposition of the study done by Alema (2008) that as the cooperative offers better price to its members agricultural produce the participation of members in selling their farm output to the cooperative increase.

\section{Functional and Financial Performance of cooperatives}

Functional Performances

To meet this objective, the study was addressed by evaluating Performance of the Cooperative Union, through describing the functions and organizational status of sample multipurpose cooperatives which comprised the union. Cooperatives' functional and organizational performances refer to the ability of cooperatives in accomplishing their planned activities within specified time and required budget allocated. The functional performance of cooperatives in input and output marketing, credit service provision, capital accumulation, membership number, and profit and loss using simple percentage analysis were evaluated based on the data available at the woreda cooperative promotion and development offices, the union and each sample multi-purpose cooperative societies.

\section{Supply of Agricultural Inputs}

Majority of peoples in the study area are engaged in agricultural activities which is dominantly the major means of earning income for consumption of goods and services. Moreover, sample respondents that were interviewed for the purpose of this study were fully engaged and fully allotted their ability of innovativeness, time, money and energy on the agricultural related activities for their livelihood.

Therefore, for greater production and productivity inorganic fertilizer and improved seeds as well as agro chemicals were played a great role as we can crosschecked from the past experience of agrarians in our locality.

As the study revealed that fertilizer is supplied and distributed by Damot Farmers' Cooperative Union in the study area as of its organization, since 2001 up to now as the most important business activity compared to other activities performed in the organization. Those fertilizers Supplied in the area are: DAP, UREA and Blended Fertilizer. The union provides the required fertilizer for both members and non-members of cooperatives.

The study result in application of Fertilizer revealed that 139(99.3\%) from 140 respondents answered 'Yes' and were Consume the rest $(0.7 \%)$ of respondent was answered 'NO' that shows he is not getting DAP and UREA from his respective multi-purpose Cooperative Society due to the absence of land on his name.

Table 4.17:The yearly Supply and Distribution of Fertilizer in Damot Farmers' Cooperative Union

\begin{tabular}{|l|l|l|l|l|}
\hline \multirow{2}{*}{ N.o } & \multirow{2}{*}{ Year } & Type of Fertilizer & $\begin{array}{l}\text { Total amount of } \\
\text { Fertilizer }\end{array}$ \\
\cline { 3 - 5 } & & DAP/qtl. & UREA/qtl & 248,951 \\
\hline 1 & 2012 & 164,195 & 84,756 & $302,978.83$ \\
\hline 2 & 2013 & $203,498.13$ & $99,480.70$ & 285,365 \\
\hline 3 & 2014 & 157,000 & 128,365 & \\
\hline \multicolumn{2}{|c|}{ Total } & $524,693.13$ & $312,601.7$ & $837,294.83$ \\
\hline \multicolumn{4}{|l|}{ G. Total }
\end{tabular}

Source: Damot Farmers' Cooperative Union 2014.

As we can see from (table 4.17) above fertilizer distribution through the union in the year 2012 was 164,195 qt. DAP and 84,756 qt UREA the total of $248,951 \mathrm{qt}$. The supply and distribution of fertilizer was increased in the year of 2013 remarkably by $21.7 \%$ compared to the year of 2012 and decreases in $9.42 \%$ in the year of 2014 . Therefore, the consumption of fertilizer was fluctuating in three consecutive years stating from 2012 up to 2014 due to the fluctuation of its price and weather condition in the study area.

Supply and Distribution of Improved Seeds

Ethiopian Improved Seeds Enterprise is the main Supplier of Improved seeds to Damot Farmers' Cooperative Union that are needed by the member multi-purpose Cooperative Societies. As we have seen in fertilizer supply 
and distribution, improved Seeds were also supplied and distributed by Damot Farmers' Cooperative Union in the study area since 2001 up to now. These improved Seeds Supplied in the area were: Maize, Wheat, Green pea, Barley, Faba bean and Teff. As cooperatives caring for others, both members and non-members of cooperatives get their required fertilizer through the above mentioned union in the area.

The study result in consumption of improved Seeds was showing that 134(95.7\%) from 140 respondents answered 'Yes' and were Consume the rest 6(4.3\%) of respondents were answered 'NO' that shows they are not taking and applying improved Seeds like: Maize, Wheat, Green pea, Barley, Faba bean and Teff from their multipurpose Cooperative Societies for maximizing the production of crops.

Table 4.18: The yearly Supply and Distribution of Improved Seeds in Damot Farmers' Cooperative Union

\begin{tabular}{|l|l|l|l|l|l|}
\hline \multirow{2}{*}{ N.o } & Type of Improved & \multicolumn{3}{|c|}{ Production Year } & Total amount \\
\cline { 3 - 5 } & Seeds/quintal & $\mathbf{2 0 1 2}$ & $\mathbf{2 0 1 3}$ & $\mathbf{2 0 1 4}$ & \\
\hline 1 & Maize & $22,249.01$ & $8,754.75$ & $10,295.875$ & $41,299.64$ \\
\hline 2 & Wheat & $2,405.28$ & 3,164 & $7,951.5$ & $13,520.78$ \\
\hline 3 & Teff & 49.95 & 143.55 & 412.15 & 605.65 \\
\hline 4 & Barley & 40 & - & - & 40.00 \\
\hline 5 & Faba Bean & - & 6 & 90 & 96.00 \\
\hline 6 & Green pea & 500 & - & - & 500.00 \\
\hline \multicolumn{2}{|l|}{$25,244.24$} & $12,068.30$ & $18,749.53$ & \\
\hline
\end{tabular}

Source: Damot Farmers' Cooperative Union 2014.

As one can show from the (table 19) above improved Seeds distribution through the Union in the year 2012 was 22,249.01 qt improved Maize seed (BH-640, BH-660 and 30G-19). The supply and distribution of improved Maize Seed was highly decreased in the year of 2013 by $39.35 \%$ compared to the year of 2012 and it also slightly increases in $1.2 \%$ in the year of 2014 . As a result, we can conclude that the consumption of Maize improved Seed fluctuates year to year by member farmers in the study area. Moreover, the performance of the union in supplying maize improved seeds also shown as fluctuation as the magnitude of consumption.

The study also revealed as the Wheat improved Seed supply and consumption level were increased slightly in $12.3 \%$ by the year of 2013 compared to 2012 and it increases in $60.25 \%$ by the year of 2014 compared to the immediate last year 2013. Therefore, we can conclude that the consumption of Wheat improved Seed by member farmers increased year to year due to knowledge of application of seeds that yield greater amount than the local variety of wheat, and the performance of the union on supplying the seed variety called "Kekeba" within three consecutive years were strengthen.

Teff improved Seed named "Kuncho" supply and consumption level were increased year to year as we have seen from (Table 4.19). In the year of 2013 and 2014 there was great improvement in quantity of seeds consumption by sample farmer members approximately 3 folds more than 2012 and similarly in 2014 approximate 3 folds more than 2013. Therefore, we can conclude that the consumption of Teff (Kuncko) improved Seed by member farmers increased year to year due to the agricultural extension workers and other agricultural experts' creation of awareness and knowledge of application of seeds that yield greater amount than the local variety of Teff.

\section{Supply and Distribution of Agro-Chemicals}

Damot Farmers' Cooperative Union distributes agro-chemicals like: Herbicides (2.4D) and Pesticides (sulfate) to the member Multi-Purpose Farmers' Cooperative Societies and those primary societies distribute chemicals to their farmer members accordingly. As the study revealed that the consumption of $2.4 \mathrm{D}$ and sulfate were $78(55.7 \%)$ from 140 respondents, while the rest $62(44.3 \%$ ) of respondents were answered 'NO' that shows they were not using Herbicides and Pesticides from their respective multi-purpose cooperative societies safe-guard their crops pre- and post-production.

Table 4.19:Types, Usage level and Price distribution of Agro-Chemicals in the study area

\begin{tabular}{|c|c|c|c|c|c|c|c|c|c|c|c|}
\hline \multirow[t]{3}{*}{ No. } & \multirow[t]{3}{*}{ Chemical } & \multicolumn{4}{|c|}{ Percentage } & \multicolumn{6}{|c|}{ Percentage } \\
\hline & & \multicolumn{2}{|l|}{ Yes } & \multicolumn{2}{|l|}{ No } & \multicolumn{2}{|c|}{ Low } & \multicolumn{2}{|c|}{ Medium } & \multicolumn{2}{|c|}{ High } \\
\hline & & No. & $\%$ & No. & $\%$ & No. & $\%$ & No. & $\%$ & No. & $\%$ \\
\hline 1 & Herbicides & 78 & 55.7 & 62 & 44.3 & 22 & 15.7 & 5 & 3.6 & 112 & 80 \\
\hline 2 & Pesticides & 78 & 55.7 & 62 & 44.3 & 22 & 15.7 & 5 & 3.6 & 112 & 80 \\
\hline & Total & \multicolumn{4}{|c|}{$140(100 \%)$} & \multicolumn{6}{|c|}{$140(100 \%)$} \\
\hline
\end{tabular}

Source: Survey result (April, 2014).

When we see the price of Agro-Chemicals provided through the union the collected data shows $112(80 \%)$ of the respondents said the price is High, 5(3.6\%) of the respondents were answered the price of Agro-Chemicals comparatively medium and the rest $22(15.7 \%)$ of 140 respondents were the price of the Agro-Chemicals were comparatively low. 
As a result we can conclude that the higher amount of price of agro-chemicals decided by the union obliges the sample cooperative members to refrain from applying those chemicals to safeguard their pre-harvest crops as well as their agricultural crop yields for maximum possible agricultural production and productivity.

Merchandizing Agricultural Products by Damot Farmers' Cooperative Union

The farmers in the study area are surplus food grain producers compared to other areas in the case of Amhara region. The area has approximately leveled landscape and comparatively productive soil type which contributed a greater value for averting the subsistence way of life for most of the people settle for last many decades.

Table 4.20: The yearly Procurement and merchandising data of Food Grain and Oil Crops in Damot Farmers' Cooperative Union

\begin{tabular}{|c|c|c|c|c|c|c|}
\hline \multirow[t]{2}{*}{ N.o } & \multirow[t]{2}{*}{ Year } & \multicolumn{4}{|c|}{ Type of merchandize Crops } & \multirow[t]{2}{*}{ Total amount } \\
\hline & & Maize/qtl. & Wheat/qtl & Teff/qtl. & Oil crops & \\
\hline 1 & 2012 & $16,140.0$ & 11,937 & 6441.88 & 512.88 & $35,031.76$ \\
\hline 2 & 2013 & $28,044.0$ & $9,588.0$ & 3000 & 351 & $40,983.00$ \\
\hline 3 & 2014 & $46,275.7$ & $23,053.14$ & 0 & 0 & $69,328.84$ \\
\hline \multicolumn{2}{|c|}{ Total } & $90,459.70$ & 44,578 & $9,441.88$ & 863.88 & $145,343.60$ \\
\hline \multicolumn{6}{|c|}{ G.Total } & $290,687.20$ \\
\hline
\end{tabular}

Source: Damot Farmers' Cooperative Union (2014).

As one can see from the (table 4.20) above food grain procurement and merchandising through the Union in the year 2012 was 16,140 qt. Maize, 11937 qt Wheat, and 512.88 qt oil Crops (Nug, Sesame and Niger seed) the total of 35,031.76 qt. The procuring and merchandizing of Maize grain was increased in the year of 2013 remarkably by $42.45 \%$ compared to the year of 2012 and it also increased in $39.4 \%$ in the year of 2014 . As a result, we can conclude that the Performance of the Union in Procurement of agricultural produces from its member primary multi-purpose farmer's cooperative societies and merchandizing of Maize grain increased year to year by approximate average of $40 \%$.

As the study reveals that Wheat grain procurement and merchandising decreased in $19.68 \%$ by the year of 2013 compared to 2012 and it increases in $58.4 \%$ by the year of 2014 compared to the immediate last year 2013 . This shows that the Procurement and merchandising of Wheat grain by the Union fluctuate year to year due to the weather conditions, shortage of wheat produces, creating more awareness to member farmers as well as Member Primary multi-purpose Cooperative Societies to sell their agricultural products the union which was organized and managed through them-selves.

\section{Financial Performance/Ratio Analysis}

For the purpose of measuring the financial performance of cooperatives different financial ratio analysis were used. Financial ratios were designed to evaluate cooperative's performance. Ratios were used as one tool in identifying areas of strengths or weakness in cooperatives. Financial ratios enable to make comparison of cooperative's financial conditions over time or in relation to other cooperatives. Ratios standardize various elements of financial data for differences in the size of a series of financial data when making comparisons over time or among cooperatives.

\section{Liquidity Ratio}

A cooperative, which intends to remain viable business entity, must have enough cash on hand to pay its debts as they come due. In other words, the cooperatives must remain liquid. One way to determine the case is to examine the relationship between a cooperative's current assets and current liabilities. Liquidity ratio also is quick measure and means to ensure whether the cooperative is capable to provide sufficient cash to conduct business over the next few months. According to Birmingham and Houston (1998) pointed out that one of the most commonly used liquidity ratio is the current ratio that is computed by dividing current asset by current liabilities.

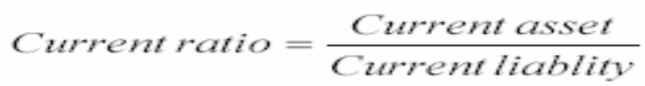

The satisfactory rate of current ratio that is accepted by most financial institutions as condition for providing loan is 2.00. With this benchmark the study was taken the three consecutive reference years (2012-2014) for the purpose of measuring the performance of current ratios and power of getting loan of sample cooperative societies. All the sample cooperatives: Wundigy Multi-purpose Farmers' Cooperative Society, Kuch Multi-purpose Farmers' Cooperative Society, Denbun Multi-purpose Farmers' Cooperative Society, TengihaAdelagata Multi-purpose Farmers' Cooperative Society, Gulim Multi-purpose Farmers' Cooperative Society, Gedamat Multi-purpose Farmers' Cooperative Society, and Damot Farmers' Cooperative Union were performed below the desirable standard. 
Table 4.21: Ratio of Sample cooperative Societies

\begin{tabular}{|c|c|c|c|}
\hline \multirow[t]{2}{*}{ Name of Cooperative Society } & \multicolumn{3}{|c|}{ Liquidity Ratio (Current Asset/Current Liability } \\
\hline & 2012 & 2013 & 2014 \\
\hline Wundigymulti-purpose Cooperative Society & 1.08 & 1.18 & 1.04 \\
\hline Kuch Multi-purpose Cooperative Society & 1.29 & 1.17 & 1.16 \\
\hline Denbun Multi-purpose Cooperative Society & 1.12 & 1.13 & 1.13 \\
\hline Tengiha-Adelagata Multi-purpose Cooperative Society & 1.04 & 1.06 & 1.05 \\
\hline Gulim Multi-purpose Cooperative Society & 1.26 & 1.18 & 1.11 \\
\hline Gedamat Multi-purpose Cooperative Society & 1.08 & 1.09 & 1.06 \\
\hline Damot Farmers' Cooperative Union & 1.09 & 1.06 & 1.06 \\
\hline Average & 1.137 & 1.124 & 1.08 \\
\hline
\end{tabular}

Source: Audit report of Sample Cooperative Societies (May, 2014)

In 2012 the average current ratio for the selected cooperatives for this purpose was 1.137. The highest ratio was 1.29, which was scored by Kuch Multi-purpose Farmers' Cooperative Society and the lowest was 1.04, which was scored by TengihaAdelagata Multi-purpose Farmers' Cooperative Society. In 2013 the average current ratio was 1.124. The average current ratio for the year 2014 became 1.087(Table 4.20). The sample cooperatives were remaining liquid because their ratios were above 1.00 , this shows us all the cooperatives were with the ability to pay their financial debits in all bench marked years. When we observe the trends and performance of all the sample cooperatives in their liquidity ratio, there was slight decrease in the liquidity ratio in all benchmarked years from 2012 to 2014, this implies that their current liabilities were rising more than their current assets. In most cases, the cooperatives have credit access from financial institutions via the regional government collateral arrangement for the purpose of agricultural inputs purchases for member and non-member farmers.

As we have seen from the study the current ratio of cooperatives is below the finance institution bench mark(2.00) for lending which may leads lenders to not be willing to extend short-term loan to the cooperatives, as the financial institutions require current ratio to remain at or above 2.00 as a condition for granting loan. The result is similar with Alema (2008) that lenders were not willing to extend short-term loan to these cooperatives due to the banks collateral policy, cooperatives low financial and managerial capability i.e. lenders require current ratio remain at or above 2.00 as a condition for granting loan and also the collateral from the lending institution.

\section{Debt Ratio/ Financial Leverage Management Ratio}

Whenever a cooperative finance a portion of asset is related with any type of financing such as debts, the cooperative is said to be using financial leverage. According Birmingham and Houston (1998) financial leverage management ratio measures the degree to which a firm is employing financial leverage. According to these authors, of the several types of financial leverage ratios, debt ratio is commonly used. It measures the portion of a firm's total asset that is financed with creditors' fund. It is computed by dividing total debt by total asset.

$$
\text { Debtratio }=\frac{\text { Total debt }}{\text { Total asset }}
$$

Table 4.22:Financial Leverage Ratio of sample Cooperative Societies

\begin{tabular}{|l|l|l|l|}
\hline Name of Cooperative Society & \multicolumn{3}{l|}{ Financial Leverage Ratio } \\
\cline { 2 - 4 } & $\mathbf{2 0 1 2}$ & $\mathbf{2 0 1 3}$ & $\mathbf{2 0 1 4}$ \\
\hline Wundigy multi-purpose Cooperative Society & 0.92 & 0.85 & 0.96 \\
\hline Kuch Multi-purpose Cooperative Society & 0.77 & 0.86 & 0.86 \\
\hline Denbun Multi-purpose Cooperative Society & 0.89 & 0.88 & 0.89 \\
\hline Tengiha-Adelagata Multi-purpose Cooperative Society & 0.96 & 0.94 & 0.95 \\
\hline Gulim Multi-purpose Cooperative Society & 0.79 & 0.85 & 0.89 \\
\hline Gedamat Multi-purpose Cooperative Society & 0.92 & 0.916 & 0.94 \\
\hline Damot Farmers' Cooperative Union & 0.915 & 0.94 & 0.94 \\
\hline
\end{tabular}

Source: Audit report of Sample Cooperative Societies (May, 2014)

As the study reveals that all the sample cooperatives financed more of their total assets from the funds which came from finance institutions. The lowest financial leverage ratio in 2012 was registered in Kuch multi-purpose farmer's cooperative society which was 77 percent and the highest financial leverage 96 percent which was the performance of TengihaAdelagata Farmers' cooperative society indicates 96 percent of the total asset of the cooperative was financed with creditors' fund, the only 4 percent of cooperatives finance was run by its own financial sources.

In the year 2013 the debt-asset ratio of Kuch, Gulim, and Damot Farmers' Cooperative union increased compared to the previous year while Wundigy, Denbun, TengihaAdelagataGedamat multi-purpose cooperative societies financial leverage ratio slightly decreases. In the year 2014 the debt-asset ratio of almost all samples cooperative societies were increased compared to the immediate previous year (Table 4.22). Therefore, the major 
source of finance to cover the shortage of budget and supply of agricultural inputs and outputs were the creditors/finance institutions.

The smaller the proportion (in most cases $<50$ percent) of the total asset financed by the financing institutions, the smaller the risk that the firm is unable to pay its debt (Brigham, et al., 1998). Having higher proportion of asset financed by the external sources (creditors) fund may lead cooperatives to the risk of bankruptcy if the management seeks to increase the debt further by borrowing additional funds. All sample cooperative societies borrowed capital had increased year to year and the investment financed by their own sources of funds got minimum in the reference years.

\section{Profitability ratio}

Profitability is the net effect of a number of policies and decisions. Profitability ratios measure how effectively a firm's management was generating profits on sales, total assets, most importantly stockholders' investment (Birmingham and Houston, 1998). These authors also suggested that the most commonly used profitability ratio refers to the return on total asset, which is computed by dividing net income by total asset.

$$
\text { Return on total asset }=\frac{\text { Net income }}{\text { Total asset }}
$$

Cooperative societies need to earn return on asset which is equal or better than the interest rate of the money they borrowed that enables them to pay the interest of the money they borrowed from financial institutions.

As we can observe from the (Table 4.23) below, the profitability ratios of the sample cooperatives were fluctuating in the past three years. In the year of 2012 the highest 63 percent earning was registered by Denbun multi-purpose cooperative society while the lowest earning was $-42 \%$ (negative 42 percent) of loss which was registered by Gedamat Multi-purpose cooperative society. In 2013 the highest 50 percent profit earning was registered by Wundigy multi-purpose cooperative society while the lowest earning was $-23 \%$ (negative 23 percent) of loss which was registered by Gedamat Multi-purpose cooperative society. Similarly when we see 2014 the highest 46 percent profit earning was registered by Gulim multi-purpose cooperative society while the lowest earning was $-6 \%$ (negative 6 percent) of loss which was registered by Wundigy Multi-purpose cooperative society.

Table 4.23:Profitability Ratio of sample Cooperative Societies

\begin{tabular}{|l|l|l|l|}
\hline Name of Cooperative Society & \multicolumn{3}{|c|}{ Profitability Ratio } \\
\cline { 2 - 4 } & $\mathbf{2 0 1 2}$ & $\mathbf{2 0 1 3}$ & $\mathbf{2 0 1 4}$ \\
\hline Wundigy multi-purpose Cooperative Society & 0.012 & 0.050 & -0.006 \\
\hline Kuch Multi-purpose Cooperative Society & 0.037 & 0.041 & 0.015 \\
\hline Denbun Multi-purpose Cooperative Society & 0.063 & 0.008 & 0.007 \\
\hline Tengiha-Adelagata Multi-purpose Cooperative Society & 0.027 & 0.012 & 0.022 \\
\hline Gulim Multi-purpose Cooperative Society & 0.036 & 0.020 & 0.046 \\
\hline Gedamat Multi-purpose Cooperative Society & -0.042 & -0.023 & 0.040 \\
\hline Damot Farmers' Cooperative Union & 0.000 & 0.015 & 0.015 \\
\hline
\end{tabular}

Source: Audit report of Sample Cooperative Societies (May, 2014)

Generally, the trend of profitability ratio of Damot Farmers' cooperative union, Kuch, GedamatWundigy multi-purpose farmers' cooperative society were increased slightly compared to the immediate last year. On the other hand Denbun, Tengiha-Adelagata and Gulim Multi-purpose Cooperative Societies return on total asset ratio were decreased due to different problems that face the cooperative society, like: Poor management of the marketing system, lack of market information, poor handling of finance. In the year of 2014 Gedamat, Gulim and TengihaAdelagata multi-purpose cooperative societies profit earnings were increased compared to the immediate year while the rest Denbun, Kuch and Wundigy multi-purpose cooperative societies profit earnings were decreased compared to last year's performance of making profit.

As we have shown from the study some of the cooperatives were not in a position to achieve the profitability ratio which is equal or better than the interest rate ( 7 per cent) with which they borrowed money from the financial institutions. As Alema, 2008 reveals in his study the possible reasons for the difference in profitability among the cooperative lies on how effectively the cooperative management is generating profit on sales, total assets, money they borrowed, repayment performances and most importantly members' investment (share capital).

\section{Opportunities and Challenges of Cooperatives}

\section{Opportunities of Cooperatives}

Now a day's, Cooperatives are play important roles in agricultural activities and saving and credit functions. Key informants interview, conducted in the study area revealed that the cooperative institutions are important.

Government support was increasing time to time through creating market linkages and coordinating different organizations to strengthen the cooperative movement. World Food Organization is becoming one of the key stakeholders in strengthening the cooperatives institutions in the study area.

Policies and legislations proclaimed by government also a great opportunity to future development of cooperatives in Ethiopia, as those legislations lead the way how cooperatives perform their functions and further 
expand their functions with their institutional development.

The market economic system that the new government brought as the main transformation in the privatization policy also play a great opportunity now a days and for the future as it pays the way to improve the cooperatives function and competitive in the business environment.

The Ethiopian cooperative development program (CDP) works with farm cooperatives members to improve productivity and competitiveness of key agricultural sector to improve farmers' income and insure great food security in the region. Activities include farmer training and coaching on technical assistance and strategic management.

The cooperative promotion bureaus starting from kebele administration to the federal ministers also a great opportunity for cooperatives to grow as fast as possible with an improved technical assistance, audit service and supervision and control activities. Cooperatives have tax free privileges in their business activity that strengths the financial performance of organizations to provide additional services to members with fair price than that of private traders.

Providing training for members and management committees, loan opportunity and development of infrastructure were the other opportunities that play an important role for future growth and development of cooperatives.

In the five years transformation plan cooperatives believed by government to market input and output of the farmers. The five year program will also establish a cooperative learning and information center (CLIC) to ensure that Ethiopian cooperatives continue to benefit from distance learning and sharing of best practices and materials (www.acdivoca.org.)

This indicates the members and employees as well as other stakeholders believe that the cooperative will success fully supply the agricultural inputs required for the farmer members and, collects and marketing members agricultural outputs in the future better than today.

\section{Challenges of Cooperatives}

The key informants interview and focus group discussion provided information on challenges of cooperatives as: limited capacity of board of directors, inadequate starting capital, poor participation of members, lack of transparency and accountability, lack of knowing rights and responsibilities, high influence of vested interest, price increase on agricultural inputs, low price of agricultural products, high cost of production, lack of availability of trained manpower, lack of information on current market, lack of communication mass-media, and lack of market infrastructure were implications for challenges of cooperatives in the study area.

There are a number of problems, which inhibit co-operative development and adversely affect performance. The most important problems are discussed below classifying into three groups (internal, external and infrastructure based problems). Out of the total respondent households, 25 per cent (35 in Number) participated in leadership of cooperatives as management committee and controlling committee.

\section{Internal Challenges}

Physical and financial properties, the systems and procedures, management committee, general assembly and cooperatives' employees constitute the internal or organizational part of cooperatives. Therefore, Poor Participation of members, limitation in exercising rights, lack of transparency and accountability, lack of equal opportunity for passing decision, failure to notify annual meeting, lack of knowing of rights and responsibilities were used as indicators to measure the internal or organizational problems of cooperatives.

Table 4.24:The distribution of Internal Challenges of Sample Cooperatives

\begin{tabular}{|l|l|l|l|l|}
\hline \multirow{2}{*}{ Internal Challenges } & $\begin{array}{l}\text { Nothing } \\
\text { Reason }\end{array}$ & Low & Medium & High \\
\cline { 2 - 5 } & Cut (\%) & Cut (\%) & Cut (\%) & Cut (\%) \\
\hline Limited Capacity of Board of Directors & $1(0.7)$ & $23(16.4)$ & $58(41.4)$ & $58(41.4)$ \\
\hline Inadequate starting Capital & $1(0.7)$ & $30(21.4)$ & $76(54.3)$ & $33(23.6)$ \\
\hline Poor Participation of members & $1(0.7)$ & $16(11.4)$ & $76(54.3)$ & $47(33.6)$ \\
\hline Lack of Transparency and Accountability & $1(0.7)$ & $33(23.6)$ & $76(54.3)$ & $30(21.4)$ \\
\hline Failure to Notify Annual meeting & $1(0.7)$ & $82(58.6)$ & $52(37.1)$ & $5(3.6)$ \\
\hline Lack of knowing rights and responsibilities & $1(0.7)$ & $47(33.6)$ & $81(57.9)$ & $11(7.8)$ \\
\hline Lack of equal opportunity for passing decision & $1(0.7)$ & $82(58.6)$ & $48(34.3)$ & $9(6.4)$ \\
\hline Limitations in Exercising Rights & $1(0.7)$ & $39(27.9)$ & $76(54.3)$ & $24(17.1)$ \\
\hline Total & $8(0.7 \%)$ & $352(31.44)$ & $543(48.49)$ & $217(19.36)$ \\
\hline
\end{tabular}

Source: Survey of 2014.

As the study result reveals and indicated in (Table 4.24), the sample respondents agreed that Limited Capacity of Board of Directors, Poor Participation of members, Inadequate starting Capital and Lack of Transparency and Accountability were the highly important problems to determine the performances of the union and cooperative societies.

Whereas, the limitation in exercising rights, lack of equal opportunity for passing decision lack of knowing 
rights and responsibilities and failure to notify annual meeting are less important internal problems of cooperatives compared to the above mentioned internal challenges of cooperatives.

Limited Capacity of Board of Directors, Inadequate starting Capital, Poor Participation of members, Lack of Transparency and Accountability, Failure to Notify Annual meeting, Lack of knowing rights and responsibilities, Lack of equal opportunity for passing decision and Limitations in Exercising Rights were scored (41.4, 54.3, 54.3, $54.3,37.1,57.9,34.3$, and 54.3) percent medially ranked problems that hinder the healthy growth and development of cooperative societies in the study area.

Limited capacities of board of directors were one of the most important internal challenges that hinder the growth of cooperative societies in the study area. Most of the cooperatives management committees were illiterate and elected members to lead the cooperative organizations with limited experience and little knowledge of managing the cooperative societies through the principles and values of cooperatives.

In adequate starting capital was the important problem which retards the growth of cooperatives performance to achieve the goals of serving its members. However, the finance collected from members and the share capital are the major sources of capital which will be required to strengthen the financial performance of cooperatives, most of members of cooperatives were failed to contribute finance for their organization.

Members can only have the opportunities to elect management committee and board of directors, approve annual budget and activities, and evaluate the audit as well as activities report in the annual meeting when they participate in annual meetings. If they failed to attend the meeting, they might not have a power to make decisions and opportunities to exercise their democratic right. Therefore, the internal problem or organizational constraint is the most important problem that requires due attention to improve the performances of cooperatives.

Overall, more than fifty percent of the sample respondents agree that the indicators for the organizational or internal problems are real bottlenecks to impede the performance of cooperatives in input output marketing. This result of study coincides with the result studied by (Jemal 2008.)

\section{External Challenges}

External challenges were important problems that retarded the growth of cooperative and which are out of the control of the organization. Cooperative societies are working in areas where government and non-governmental as well as private enterprises are operated that might have a suppressive effect on cooperatives healthy functioning. The challenges of cooperatives listed on table 4.25 are assumed to represent external challenges of cooperatives in the study area. Price increments on agricultural inputs were the most important external challenge that hinders the participation of members on purchase of input from cooperatives as well as it has a great challenge on the productivity of agriculture in the study area.

Table 4.25: The external Challenges of sample Cooperatives societies

\begin{tabular}{|l|l|l|l|l|}
\hline \multirow{2}{*}{ External Challenges } & Nothing Reason & Low & Medium & High \\
\cline { 2 - 5 } & Cut (\%) & Cut (\%) & Cut (\%) & Cut (\%) \\
\hline High Influence of vested interest & $1(0.7)$ & $55(39.3)$ & $63(45)$ & $21(15)$ \\
\hline Price increase on agricultural inputs & $1(0.7)$ & $28(20)$ & $49(35)$ & $62(44.3)$ \\
\hline Existence of other competitors & $1(0.7)$ & $68(48.6)$ & $59(42.1)$ & $12(8.6)$ \\
\hline Low price of agricultural products & $1(0.7)$ & $50(35.7)$ & $63(45)$ & $26(18.6)$ \\
\hline High cost of production & $1(0.7)$ & $27(19.3)$ & $52(37.1)$ & $60(42.9)$ \\
\hline Total & $1(0.7)$ & $228(32.58)$ & $286(40.48)$ & $181(25.88)$ \\
\hline
\end{tabular}

Source: Survey of 2014.

High costs of production on the process of producing agricultural outputs were the second major challenges that have a suppressive effect on the productivity of the farmer members in the area. Another major problem that affects participation of members and performance of cooperatives most significantly was the interference from other group like: local and district administrators, promoters and other individuals who have vested interest on the expenses of cooperatives.

On the other hand, existence of unfair competition and low price of agricultural outputs were the most important problems affecting cooperatives performance. The unfair price offered to agricultural produces as a result of unfair competition was limiting cooperatives' scope of services and members competitiveness in the market. The study result revealed that sample respondents also agreed that price increase for agricultural input over time, high cost of production were the most important problems that are affecting members' participation to improve performance of cooperatives.

Price increase of agricultural inputs and High cost of Production were scored 44.3 per cent and 42.9 percent respectively therefore we can conclude as those of two external challenges were the most important challenges which hinders active participation of members and performance of cooperatives in the study area.

High influence of vested interest of other parties, existence of unfair competition and low price of agricultural produces were scored $(45,42.1,45$ percent) respectively when we classified these problems as medium challenges of cooperatives.

Generally, due to those recurrent external problems cooperatives were unable to compete in the market for 
supplying members' agricultural produces and providing the maximum possible services to its members.

\section{Infrastructural Challenges}

As the study revealed that infrastructural challenges are challenges that hinders the well-functioning and facilitation of cooperatives due to lack of availability of trained manpower, lack of information on current market, lack of mass-medias for communication purposes, lack of market infrastructure, shortage of store and transportation facilities shortage of linkage with financial institutions and shortage of electrification.

Availability of trained man power is the determining factor that retards or accelerates the growth and development of cooperatives. As the study revealed that lack of availability of trained manpower was the most important challenge that the cooperative societies faces. 46.4 per cent of respondents were replied that lack of trained manpower is the highly influential factor that hinders the well-functioning of cooperatives in the study area. The day to day activities of cooperatives are managed by the employees whose academic background did not exceed the secondary school. The employees are not well literate and experienced to assist the management committee of cooperatives in passing decisions and follow upping the activities of the institution. Consequently, cooperatives were poor in their performances and serving of their members as well.

Table 4.26: The distribution of infrastructural challenges of sample cooperatives

\begin{tabular}{|l|l|l|l|l|}
\hline \multirow{2}{*}{ Infrastructural Challenges } & Nothing Reason & Low & Medium & High \\
\cline { 2 - 5 } & Cut (\%) & Cut (\%) & Cut (\%) & Cut (\%) \\
\hline Lack of availability of Trained Manpower & $1(0.7)$ & $29(20.7)$ & $45(32.1)$ & $65(46.4)$ \\
\hline Lack of information on current market & $1(0.7)$ & $13(9.3)$ & $77(55)$ & $49(35)$ \\
\hline Lack of communication mass-media & $1(0.7)$ & $42(30)$ & $55(39.3)$ & $42(30)$ \\
\hline Lack of market infrastructure & $1(0.7)$ & $30(21.4)$ & $82(58.6)$ & $27(19.3)$ \\
\hline Shortage of store and transportation facility & $1(0.7)$ & $47(33.6)$ & $75(53.6)$ & $17(12.1)$ \\
\hline Shortage of linkage with financial institutions & $1(0.7)$ & $53(37.9)$ & $71(50.7)$ & $15(10.7)$ \\
\hline Shortage of electrification & $1(0.7)$ & $69(49.3)$ & $63(45)$ & $7(5)$ \\
\hline Total & $7(0.7)$ & $283(28.89)$ & $468(47.76)$ & $222(22.64)$ \\
\hline
\end{tabular}

Source:Survey of 2014.

Lack of information on current market was also one of the most important challenges that put its massive suppressive effect on the marketing of agricultural input and output of cooperatives and members. Due to lack of current information the members are not beneficial from the peak price times of agricultural produces and lower price of agricultural inputs. 35 per cent of respondents were agreed upon the challenges of lack of information on current market situation laid down the major problem for inhibiting to get the optimum price level for both agricultural input purchase time and agricultural output marketing times.

The respondents were agreed on the lack of communication facilities, marketing infrastructure, storage and transportation facilities, linkage with financial institutions, and electrification are affecting the performance of cooperatives and members participation on marketing of agricultural input and output with cooperative institutions. Cooperatives and member farmers may require information for planning, implementing farm production and marketing. As the seasonality of agriculture information on weather conditions have a great impact on the productivity and production of agriculture.

In addition, electrification was among the important problems of infrastructure to affect performances of cooperatives. Lack of electricity on the rural area is becoming an impeding factor to cooperatives function to use advanced technologies and investing on agro-processing industries.

Increase in the agricultural production, should be achieved through the use of improved technologies. At the same time farmers should have access to market for their produces. The bulky and perishable nature of agricultural input and output requires massive transportation facilities, road networks, adequate warehouses, packaging materials, proper way of post-harvest handling and other infrastructural facilities. This resulted into significant increase of cost of transactions. High transaction costs coupled with seasonal nature of demand and supply for agricultural input and output respectively, it is usually evident that price increases during peak demand period to input and decreases in supply peak period for the produces. Consequently, cooperatives fail to compete and give adequate services to members due to inefficient management capacity (Jemal, 2008).

\section{Summary of Members' Suggestions}

At the end of interviews, sample respondents were requested to offer their suggestion for better improvement of cooperatives performance in serving its members on supplying agricultural inputs and outputs. Those suggestions summarize into five categories.

Education and Training for members, management committee \& Employees: Education and Training that have to be provided for members of cooperatives management body and employees of cooperatives were strengthen the participation of members in each and every activity of cooperatives. Providing education and training on regular basis is one of the fundamental principles of cooperatives which strengthen the knowledge of members on operations of cooperatives and its importance. Effective change of co-operatives can only be realized if the members are actively participating in their co-operative affairs. Cooperative organizations involving in 
providing training must be well organized to train members in the advantages, duties and responsibilities, principles and values of cooperatives and how to control and supervise cooperatives operational activities. Management committees of cooperatives are the responsible bodies to lead the overall activities. Therefore, training and education have to be conducted to those management committees with role and responsibility of the committee, values and principles of the cooperatives and how to manage the human, financial and physical resources of cooperatives. As the study conducted reveals that 90.7 percent of the respondents were agreed up on the provision of education and training for cooperative members, management committee and employees of cooperatives while the rest 9.3 percent of the respondents were not suggest providing education and training.

Minimize Agricultural Input Price: The study result indicates that 99.3 percent of respondents were suggesting that there must be fair price for agricultural inputs. Cooperative societies have to decrease the margins that the cooperative societies were collect from members as well. The fair price for agricultural input encourages farmers to use the recommended amount of inputs for their production purpose and this will lead to farmers to success of maximum production. Supplying the agricultural inputs on time has to be crucially performed because of the seasonality (rain fall dependent) nature of farming system in the study area.

Improve Provision of Credit: The study result reveals 100 per cent of the sample respondents suggested the importance of sources of loan and systems developed to manage loan available. Credits have to be given for farmers especially agricultural inputs to cover their lands with the seeds and fertilizer for better productivity. Without credit no or insignificant number of farmers may purchase the fertilizer and improved seeds. Reliable source of fund for operation and investment is badly required by the cooperatives and members as well. Members' ability and willingness to finance cooperatives is limited for various reasons. Loan disbursed need to be collected properly so that cooperatives can cover their fund as well as operational costs in disbursing and collecting loans to and from cooperatives. The Cooperative societies have also try to fairly calculating the amount of interest for the loan provided for individual farmers.

Maximize Agricultural Output Price: Maximizing agricultural output price is one of the important decisions to maximize the farmers' earnings and standard of living. If cooperatives are capable and competent to capture members market by offering fair prices, the access of alternative market opportunities would never be so crucial issue to cooperatives. As the study reveals that 99.3 percent of the respondents were suggested that the importance of maximizing agricultural inputs were an important function the cooperative societies have to apply for their farmer members' wellbeing and increment of competitiveness in the market economic system. On time lading of agricultural products must be applied for getting a good market for the products as well as to control pests that damage most of agricultural produces.

Creating Awareness about Cooperatives: Creating awareness is creating the sense of ownership to members on cooperatives and it increases the sense of rely on their institutions. 90.7 percent of respondents were suggested that the responsible bodies have to try their best for creating cooperative awareness for the members like; cooperatives importance, values and principles and ownership of the institution. The rest 9.3 percent of the respondents were not suggest creating awareness to members and other cooperative employees as well as management bodies. Members also suggest that the union have to share the best experiences from other cooperative societies and unions to take the best practices and widening and improving its functions.

Table 4.27:Distribution of Suggestions of Sample Respondents

\begin{tabular}{|l|l|l|l|l|}
\hline No. & Suggestion & Response & Number of Respondents & Percent \\
\hline 1 & Education and Training for members, & Yes & 127 & 90.7 \\
\cline { 3 - 5 } & management committee \& Employees & No & 13 & 9.3 \\
\hline 2 & Try to minimize Agricultural Input Price & Yes & 139 & 99.3 \\
\cline { 3 - 5 } & & No & 1 & 0.7 \\
\hline 3 & Improve Provision of Credit & Yes & 140 & 100 \\
\cline { 3 - 5 } & & No & 0 & 0 \\
\hline 4 & Try to Maximize Agricultural Output Price & Yes & 139 & 99.3 \\
\cline { 3 - 5 } & & No & 1 & 0.7 \\
\hline 5 & Creating Awareness About Cooperatives & Yes & 127 & 90.7 \\
\cline { 3 - 5 } & & No & 13 & 9.3 \\
\hline
\end{tabular}

Source: survey result (April, 2014)

\section{CHAPTER FIVE \\ CONCLUSION AND RECOMMENDATION CONCLUSION}

Cooperatives, as economic enterprises and as self-help organizations, play a meaningful role in uplifting the socioeconomic conditions of their members and their local communities. Cooperative is expected to play crucial role in the rural part of the country to speed up agricultural growth through supply of agricultural input and merchandising output in market for the rural farmer members in the country. Of the different type of cooperatives operating in 
the rural part of the country, MPCSs has a significant role. Multipurpose farmer cooperative society is organized to render multifaceted service in the rural area to its members and nearby rural community in cost effective manner than private owned firms. Moreover, MPCSs improve farmers' access to agricultural inputs and market agricultural outputs and increase their bargaining power. This insure timely supply of farm inputs (like improved seed, fertilizer and others), marketing of farmers' output, create competitive marketing system and attain economies of scale which is impossible at individual farmer level.

This study attempted to identify the opportunities and challenges of marketing of agricultural inputs and outputs in the study area: assessing the performance of union and Multi-purpose cooperative societies in agricultural inputs and outputs marketing, identifying the opportunities of cooperatives, internal, external and infrastructural challenges in agricultural inputs and outputs marketing in the study area and proposing the interventions required to solve the problems faced by the cooperatives.

To accomplish this study both primary and secondary sources that combine qualitative and quantitative data were used. The descriptive statistics were also used for analyzing the data in addition to the ratio analysis. The age, family size, educational background, sex, on-farm and non-farm income, annual income, members expenditure, participation of members on cooperative affairs, membership duration and status, members awareness about cooperatives, satisfaction of members, land, TLU, Share contribution, crop production, credit provision proximity to market place, regularity of market service, and perceived agricultural input and output price disparity have a great influence on the performance of agricultural input and output marketing of cooperatives in the study area.

Volume of agricultural inputs and outputs marketed by cooperatives were analyzed using tables and percentage. The result of performance of MPCSs was presented organizing into two categories such as functional and financial performances. The consumption of fertilizer and Maize improved Seed were fluctuating in three consecutive years stating from 2012 up to 2014 due to the fluctuation of its price and weather condition in the study area, the consumption of Teff (Kuncko) improved Seed by member farmers increased year to year due to the agricultural extension workers and other agricultural experts' creation of awareness and knowledge of application of seeds that yield greater amount than the local variety of Teff, the higher amount of price of agrochemicals decided by the union obliges the sample cooperative members to refrain from applying those chemicals to safeguard their pre-harvest crops as well as their agricultural crop yields for maximum possible agricultural production and productivity, the Performance of the Union in Procurement of agricultural produces from its member primary multi-purpose farmer's cooperative societies and merchandizing of Maize grain increased year to year by approximate average of $40 \%$, the Procurement and merchandising of Wheat grain by the Union fluctuate year to year due to the weather conditions, shortage of wheat produces, creating more awareness to member farmers as well as Member Primary multi-purpose Cooperative Societies to sell their agricultural products the union which was organized and managed through them-selves.

The financial performance of the cooperatives was examined using the financial ratios. Current ratio, debt ratio and net profit margin ratio indicators were used to examine the financial performance of the cooperatives. Ratios were analyzed taking the three audit year's financial data (2011, 2012 and 2013) for six multi-purpose Farmers' cooperative societies. The liquidity analysis showed that the current ratio of cooperatives under investigation is below the finance institution bench mark(2.00) for lending which may leads lenders to not be willing to extend short-term loan to the cooperatives, as the financial institutions require current ratio to remain at or above 2.00 as a condition for granting loan. All sample cooperative societies under investigation borrowed capital had increased year to year and the investment financed by their own sources of funds got minimum in the reference years. On average $90 \%$ of the assets of the cooperatives was financed with creditors fund in the audit years under analysis. The profitability ratio of the cooperatives under investigation showed that the profitability of the cooperatives was weak.

Participation of members based on some indicators were examined in the core function that the cooperatives required to be successful, 19.2 percent of total participants were actively participate in all cooperative affairs, 39.6 percent of total participants were participating on cooperative affairs sometimes while the rest 41.2 the higher proportion of the respondents were not actively participate on cooperative affairs and this is the bad news for cooperatives better future and growth.

Government support, Policies and legislations proclaimed by government, The market economic system that the new government brought as the main transformation in the privatization policy, The Ethiopian cooperative development program (CDP) which works with farmers' cooperative societies, The cooperative promotion bureaus starting from kebele administration to the federal ministers, Cooperatives with tax free privileges in their business activity, Providing training for members and management committees, loan opportunity and development of infrastructure and in addition in the five years transformation plan cooperatives believed by government to market input and output of the farmers are the great opportunities of the cooperative societies development in the future in the study area.

In this study the major challenges in the agricultural input and output marketing services delivered by the cooperatives identified in the study area were: Limited Capacity of Board of Directors (41.4), Inadequate starting 
Capital (23.6), Poor Participation of members (33.6), Lack of Transparency and Accountability (21.4), Lack of equal opportunity for passing decision (6.4) and High cost of production (42.9), Price increase on agricultural inputs (44.3) Lack of communication mass-media(30), Lack of information on current market (35), and Lack of availability of Trained Manpower (46.4) percent are the challenges which inhibit co-operative development and adversely affect performance among others.

Accordingly, the respondents under the investigated cooperative societies suggested education and training for members (90.7), management committee \& employees (99.3), try to minimize agricultural input price (100), improve provision of credit (99.3), maximize agricultural output price (99.3), creating awareness about cooperatives (90.7) are among the possible solutions to improve the cooperative societies weak performances.

\section{RECOMMENDATION}

On the basis of findings and conclusion reached in this study, to enhance the performance of MPCSs in marketing of agricultural inputs and outputs in the study area; the following recommendation are forwarded to cooperatives themselves, members, concerned government stakeholder, non-government organization and other stakeholders who strive to improve cooperative role and performance in the rural part of the country. Among the variables used in this study age, family size, educational background, sex, on-farm and non-farm income, annual income, members expenditure, participation of members on cooperative affairs, membership duration and status, members awareness about cooperatives, satisfaction of members, land, TLU, Share contribution, crop production, credit provision proximity to market place, regularity of market service, and perceived agricultural input and output price disparity have a great influence on the performance of agricultural input and output marketing of cooperatives in the study area. In line with this, the following suggestions had been forwarded.

Providing Education and training for management bodies and members of cooperatives: Through giving due attention on education and training development and awareness among members have to be maintained. Efforts have to be done to raise awareness of members on the principles and values of cooperative societies including their duties and responsibilities. Besides, Board of directors is expected to run the activities of cooperatives. A performance of cooperatives depends on the strength of Board in formulating appropriate policy to the management or employees. The promotional departments at district or regional level should assess the situation to design training programs to improve the capacity of the Board of directors and employees of cooperative societies. Raising awareness of members, up grading the capacity of Boards and employees are the most important efforts to improve the performance of MPCSs.

Hiring Professional Management: One of the very important constraint of the agricultural input and output marketing activity of the cooperatives is lack of professional management. Therefore, the cooperative management committee and the cooperative promoters should take appropriate action in hiring professional staffs depending on the financial capacity of the cooperatives in order to enable the respective cooperative society solve its management problem.

Increase the cooperatives' own fund through sales of share capital and running profitable business: The poor functional, organizational and financial performances; poor participation cooperative members in various activities of cooperatives are the major manifestations that experienced in the study area. Therefore, to overcome the problems the appropriate intervention should be applied by government and other concerned bodies. Having higher proportion of asset financed by the creditors fund may lead the cooperatives to the risk of bankruptcy though the board of directors, management committee of cooperatives and the staff should strive to seek a solution to increase the cooperatives' own fund through sales of share capital to its members and running profitable business through massive transaction with members in marketing of agricultural inputs and outputs.

Exploiting the current supportive rules and regulations

The internal, external and infrastructural challenges that affect performance of MPCSs should also be minimized for the future growth of cooperatives through the application of different mechanisms and exploiting the possible opportunities that are created by the contemporary rules and regulations for encouraging the growth of cooperative societies.

Vertical and horizontal integrations: Vertical and horizontal linkages of cooperatives should be taken in to consideration among the various cooperative societies to solve their financial problem and bearing experiences for managing cooperatives through the formation of saving and credit cooperative unions at Woreda level forming Cooperative bank and organizing cooperative federation on the country level.

Develop Experience Sharing: The union as well as the member cooperative societies has to share experiences from other areas where the capacity and performance of cooperatives are enough to take lesson for further improvement.

\section{LIMITATIONS, ANDDIRECTION FOR FUTURE RESEARCH WORK}

This study attempted to find out an important finding with regard to Opportunities and Challenges of Damot Farmers' Cooperative Union in marketing of Agricultural inputs and Outputs in Bure woreda. However, due to 
constraints of finance and purpose this study is limited to one woreda level and confined to rural agricultural cooperatives which are engaged in agricultural inputs and outputs marketing which comprised Damot farmers' cooperative Union which makes difficult to generalize and make inference to the whole country or regional level. Thus, there is a need to make in-depth survey and applying some statistical models in this regard by considering other woredas' of the region or the country to find out the Opportunities and Challenges of multipurpose cooperatives in the marketing of agricultural inputs and outputs so as to improve the performance of cooperatives and agricultural production and productivity of the farmer members.

\section{BIBLIOGRAPHY}

AlemaWoldemariam, (2008). Analysis of the Role of Cooperatives in Agricultural Input and Output, Marketing in Southern Zone of Tigray, Ethiopia.

Alemayehu, Z. (2002) “Co-operatives in Ethiopia: Past Experiences and Future Trends” in Self-help Initiatives in Ethiopia: Prospects and Challenges, Redie, A. and Hinrichsen, I. 2002

ADLI, (Agricultural Development Lead Industrialization), (2001). Rural Development Policies and Strategies: Department of press and Audiovisual, Ministry of Information. Addis Ababa, Ethiopia.

AsfawNegassa, (2003). The Effects of marketing policy changes on spatial Grain market Efficiency: Extension to the parity Bounds Model and an application to Ethiopia. A paper presented at the Harnessing markets for Agricultural Growth in Ethiopia.

ATA (Ethiopian Agricultural Transformation Agency. National Growth \& Transformation Plan. Retrieved 12 January 2014.

Becker, S. O. and Ichino, A., 1997. Estimation of average treatment effects based on Propensity Scores: The Stata Journal, 2(4): 1-19.

Byerlee, D., Spielman, D., Alemu, D. and Gautam, M. (2007) Policies to Promote Cereal Intensification in Ethiopia: A Review of Evidence and Experience, IFPRI Discussion Paper 707, Washington DC, USA: International Food Policy Research Institute.

Bijman, J. (2002), Essays on Agricultural Co-operatives; Governance Structure in Fruit and Vegetable Chains, Rotterdam: ERIM (PhD Thesis).

Bringham, E.F. and J.F. Houston, (1998). Ratio Analysis. In: Dryden Press (ed.), Fundamentals of Financial Management. The Dryden press, Orlando, Florida, U.S.A., pp. 7093.

BWAO (Bure Woreda Agriculture Office), (2013). Annual Report.

Center for Cooperatives, (2004). Working together for stronger cooperatives. University of Wisconsin, Madison, U.S.A. www. Wis. Edu/uwcc. Accessed In October 2013.

Chukwu, S.K., (1990). Economics of the Cooperative Business Enterprise. Marburg, Germany.

C. R. Kothari. (2004). Research methodology: methods and techniques, 2nd ed., New Age International Ltd. New Delhi, India.

CSA (Central Statistics Agency), (2007). Summary and statistical report of population and housing census, Addis Ababa, Ethiopia

CSA (Central Statistical Authority). (2008). Area and production forecasts of major crops: agricultural sample survey data, Addis Ababa, Ethiopia.

CSA (Central Statistical Authority). (2010). Area and Seed Distribution Coverage for major Crops: Agricultural sample survey data. Addis Ababa, Ethiopia.

Daniel Belay, (2006). Performance of primary agricultural cooperatives and determinants of members' decision to use as marketing agent in AdaaLliben and Lume districts MSc. thesis in agricultural Economics, Alemaya University, Ethiopia.

DawitAlemu, (2005). The status and challenges of agricultural marketing in Ethiopia, Melkassa Agricultural Research Center, EARO Paper presented at a panel discussion organized by the Ethiopian Association of Agricultural Professionals (EAAP), Addis Ababa, Ethiopia.

Demeke, M., Kelly, V., Jayne, T.S., Said, A., LeValle'e, J.C., Chen, H.,(1998). Agricultural Market performance and determinants of fertilizer use in Ethiopia. Working Paper 10. Grain Market Research Project, Ministry of Economic Development and Cooperation, Addis Ababa.

DSA (Development Studies Associates),(2006). Study on Improving the Efficiency of Input Markets. Addis Ababa: Ministry of Agriculture and Rural Development, Federal Democratic Republic of Ethiopia.

DessalegnRahmeto, (1994). After Mengistu, a Mammoth Task. Ceres No 147. 1994.

EleniGabre-Madhin, Bonger, and Suresh Babu, (2004). Ethiopian Development Research Institute and International Food Policy Research Institute Washington.

EFDR, (2005). Agricultural input and product marketing strategy and Implementation mechanisms, Addis Ababa, Ethiopia.

FAO/WFP, (2006). Special report crop and food supply assessment mission to Ethiopia. Addis Ababa, Ethiopia.

NegaritGazeta, (1966). The Imperial Government of Ethiopia Ministry of Pen. Co-operative Societies 
Proclamation No. 241, 3rd September. 1966, Addis Ababa.

NegaritGazeta (1978). The Provisional Military Administration Council. Co-operative Societies Proclamation No. 138, 3rd March, 1978, Addis Ababa.

Federal NegaritGazta of the EPRDF (1998) cooperative society's proclamation No.147/1998, Addis Ababa.

FCA (Federal Cooperative Agency), (2005). Cooperative annual magazine. Addis Ababa,Ethiopia.

GebremeskelDessalegn, (2002). Market structure, conduct and performance: constraints on performance of Ethiopian grain markets, working paper 8 grain market research project ministry of economic development and cooperation, Addis Ababa, Ethiopia.

GebruDesta(2007). 'Competitive advantage of Agricultural Cooperatives' Services in Rural Areas of Tigray, Ethiopia. MSc.Thesis, submitted to Department of Food Business and Development, National University of Ireland, Cork.

Getahun Degu (2004), Assessment of factors affecting adoption of wheat technology and its impact: the case of Hulu woreda, Ethiopia, M.Sc. Thesis, Agricultural Economics,Alemaya University, Ethiopia.

GizachewGeteneh, (2005). Dairy Marketing Patterns And Efficiency: A Case Study Of Ada'aLiben District Of Oromia Region, MSc Paper, Alemaya University, Ethiopia.

GTP (Growth and Transformation Plan). Ethiopia's Growth and Transformation Plan (GTP), a medium term strategic framework for the five-year period (2010/11-2014/15), September 2010, Addis Ababa.

HaileselassieGirmay, (2003). The Benefits of Cooperative Membership: A Cooperative Study in SaesieTsaedaEmba District, Tigray Region, Ethiopia.

Hajela, T.N., (1990). Principles, Problems, and Practices of Cooperation. ShivalalAgrawala\& Co Agra. New Delhi.

International Co-operative Alliance (ICA), (1995). Statement on the Co-operative identity, in review of international cooperation, Vol.88, No.30.

International Labours Organization (ILO) / International Co-operative Alliance (ICA), (2003). Cooperatives and the MDGs, Cooperative Branch and Policy Integration. Geneva, Switzerland.

Jemal Mahmud, (2008). Analysis of the role of cooperatives in agricultural input output marketing in eastern zone, Tigray region, Ethiopia.

Kisi Tesemma, (2013). Prospects and Challenges of Multipurpose Cooperatives in Seed Supply Chain: the Case of Dodola, Oromia, Ethiopia,Mekelle, Ethiopia.

Kotler, P. and G. Armstrong, (2003). Principle of Marketing, 10th Edition. Hall of India Pvt.Ltd., New Delhi. pp 5-12.

Kotler. P., (2003). Marketing Management. Prince Hall, Delhi-India.

Krishaswami O.R and V. Kulandaiswamy. (1992). Theory of Cooperation: An In depth Analysis. Coimbatore: Shanma Publications.

Ministry of Finance and Economic Development (MoFED), (2005). Sustainable Development and Poverty Reduction Program, Addis Ababa, Ethiopia.

Ministry of Finance and Economic Development (MoFED), (2006). "Ethiopia: Building on Progress.” A Plan for Accelerated and Sustained Development to End Poverty (PASDEP) (2005/6-2009/10). vol.1.

Mulat,(1999). The Response of Ethiopian Grain Market Liberalization. Working Paper 6, GMRP/MEDaC, Addis Ababa, Ethiopia.

Ortman, et al., (2006). "Small Scale Farmers in South Africa; Can Agricultural Cooperatives Facilitate Access to Input and Markets? College of Agriculture, Food and Environmental Science, University of Minnesota, Staff Paper Serious.

Samuel Gebreselassie, (2006). Intensification of Smallholder Agriculture in Ethiopia: Options and Scenarios, Paper prepared for the Future Agricultures Consortium Meeting at the Institute of Development Studies, Addis Ababa, Ethiopia.

Singh, (2002). Rural Marketing, with special focus to input marketing, India.

TechaneAdugna, (2002). Determinants of Fertilizer Adoption in Ethiopia: the case of major cereal producing areas, M.Sc. Thesis, Agricultural Economics, Alemaya University, Ethiopia.

TeferaDerbew (2004). Determinants of smallholder farmers' demand for non-formal credit: the case of Farta woreda, M.Sc. Thesis, Agricultural Economics, Alemaya University, Ethiopia.

TeferiWondale, (2003). Trends in and Determinants of Fertilizer Use in Gozamin woreda, Amhara Region, M.Sc. Thesis, Agricultural Economics, Alemaya University, Ethiopia.

World Bank, (2008). Enhancing Agricultural Innovation.

Yigremew Adal, (1998). Necessity and Neglect: Rural Local Organizations and Rural Development in Ethiopia, Paper presented at the Ninth Annual Conference the Ethiopian Economy, Organized by the Ethiopian Economic Association and Department of Economics, Addis Ababa.

ZerihunAlemayehu, (1998). Cooperatives Movement in Ethiopia, Unpublished paper presented in the National Workshop in Addis Ababa, Ethiopia. 